



\section{Integration gennem voksen- og efteruddannelse}

Landerapport Danmark

Tinne Geiger og Karen Lund 
Integration gennem voksen- og efteruddannelse

Landerapport Danmark

TemaNord 2010:561

(C) Nordisk Ministerråd, København 2010

ISBN 978-92-893-2091-7

Publikationen er tilgængelig som Print on Demand (PoD) og kan bestilles på www.norden.org/order. Fler publikationer findes på www.norden.org/publikationer.

\section{Nordisk Ministerråd}

Ved Stranden 18

1061 København K

Telefon (+45) 33960200

Fax (+45) 33960202

\author{
Nordisk Råd \\ Ved Stranden 18 \\ 1061 København K \\ Telefon (+45) 33960400 \\ Fax (+45) 33111870
}

www.norden.org

\section{Det nordiske samarbejde}

Det nordiske samarbejde er en af verdens mest omfattende regionale samarbejdsformer. Samarbejdet omfatter Danmark, Finland, Island, Norge og Sverige, samt de selvstyrende områder Færøerne, Grønland og Åland.

Det nordiske samarbejde er både politisk, økonomisk og kulturelt forankret, og er en vigtig medspiller i det europæiske og internationale samarbejde. Det nordiske fællesskab arbejder for et stærkt Norden i et stærkt Europa.

Det nordiske samarbejde ønsker at styrke nordiske og regionale interesser og værdier i en global omverden. Fælles værdier landene imellem er med til at styrke Nordens position som en af verdens mest innovative og konkurrencedygtige regioner. 


\section{Indhold}

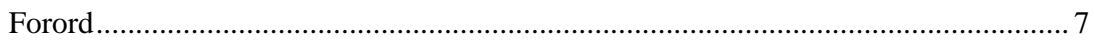

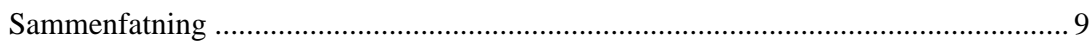

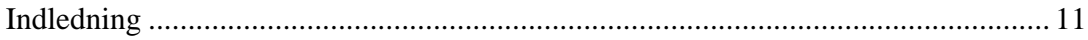

1. Indvandrere og efterkommere i Danmark........................................................... 13

2. Nationale integrationsstrategier ............................................................................ 17

3. Initiativer til styrkelse af integration gennem ordinær voksen- og efteruddannelse ..................................................................................... 27

3.1 Beskrivelse af voksen- og efteruddannelsessystemet ......................................2 27

3.2 Integrationsaktiviteter inden for voksen- og efteruddannelserne...................... 28

4. Særlige voksen- og efteruddannelsestilbud til styrkelse af integrationen ............... 55

4.1 Beskæftigelsesrettede initiativer.................................................................... 56

4.2 Initiativer med særligt fokus på guide-/mentorordninger ................................. 58

4.3 Initiativer med særlig fokus på kvinder.......................................................... 59

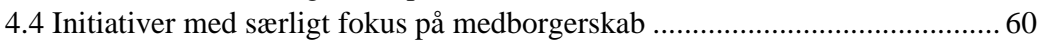

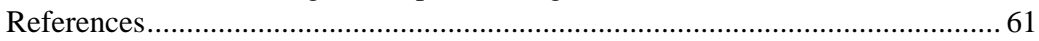





\section{Forord}

Nationalt Center for Kompetenceudvikling har foretaget en komparativ undersøgelse af integration af indvandrere og efterkommere gennem voksenog efteruddannelse i de nordiske lande.

Resultaterne af undersøgelsen fremlægges i fem nationale rapporter og en rapport med tværgående analyser og sammenfatninger. Denne rapport beskriver de danske resultater. Alle rapporterne kan findes på www.ncfk.dk under publikationer.

Undersøgelsen er gennemført af Nationalt Center for Kompetenceudvikling i samarbejde med Islands Universitet, Institut for fremmedsprog, litteratur og lingvistik, Norges Teknisk-Naturvidenskabelige Universitet, Forskningsenheden voksne i livslang læring, Gøteborgs Universitet, og Åbo Akademi i Vasa, Det pædagogiske fakultet.

Undersøgelsen er gennemført på opdrag af og med økonomisk støtte fra Nordisk Ministerråd.

Undersøgelsen er den første samlede tværnordiske kortlægning af området. Det er vor opfattelse, at samspillet mellem integration og voksenuddannelse er både aktuelt relevant og politisk vigtigt. Det er vort håb, at det fremlagte materiale vil kunne bidrage til nordisk inspiration og handling for såvel uddannelsesadministratorer, forskere som praktikere. 


\section{Om NCK}

Nationalt Center for Kompetenceudvikling indsamler, dokumenterer og formidler viden om metoder og redskaber, der anvendes til at planlægge og gennemføre VEU og kompetenceudvikling i offentlige og private virksomheder.

Opgaven løses i et samarbejde mellem medarbejdere fra Danmarks Pædagogiske Universitetsskole, Aarhus Universitet, Anvendt Kommunal Forskning, Videncenter for Uddannelses- og Erhvervsvejledning, Nationalt Videncenter for Realkompetencevurderinger og CARMA, Aalborg Universitet.

\section{Bjarne Wahlgren}

Centerleder

Januar 2010 


\section{Sammenfatning}

Beskæftigelse og selvforsørgelse har været centrale mål for integrationsindsatsen i hele den omfattede periode, der går fra slutningen af 1990'erne. Der er et fortsat fokus på sprog som en afgørende forudsætning for integration på arbejdsmarkedet. Fokus har dog ændret sig fra en antagelse om at sprog skulle læres før der kunne blive tale om deltagelse på arbejdsmarkedet, til nu i højere grad at blive set i samspil med beskæftigelse.

Det øgede fokus på beskæftigelse går igen i ændringen af danskuddannelsesloven i 2003, der udover at øge erhvervs- og arbejdsmarkedsretningen havde til formål at gøre Danskuddannelsen mere omkostningseffektiv. Det skulle blandt andet ske ved tidsmæssigt og geografisk fleksibilitet, ved øget samspil med arbejdsmarkedet og ved at indføre en ny incitamentstruktur i form af taxameterstyring.

Sprogundervisning og arbejde eller praktik bliver således i stigende grad kombineret i integrationsprojekterne. Det gælder et øget fokus på arbejdsmarkedsretteede forløb i forbindelse med danskuddannelserne, og det gælder i forbindelse med en række af de særlige initiativer som er specifikt rettet mod indvandrere. Kombinationen lader til at have positiv effekt med hensyn til såvel sprogindlæring som mulighederne for beskæftigelse.

I relation til uddannelsesområdet er der ligeledes stigende fokus på at koble fag- og sprogundervisning. Også her viser erfaringerne at udbyttet af begge dele øges når der etableres god sammenhæng mellem de to.

I takt med at andelen af indvandrere på flere uddannelser er steget, er der i forbindelse med uddannelserne udviklet særlige tiltag som er specifikt rettet mod tosprogede. Det drejer sig om forsøg med Dansk A som andetsprog på HF-enkeltfag, Dansk som andetsprog på AVU, mens der på AMU er etableret særlige forløb for indvandrere, hvor en eller flere uddannelser kan kombineres med Dansk som andetsprog. 
For undervisere i dansk som andetsprog på både Danskuddannelsen, AVU og AMU er det et krav at de skal have gennemført Uddannelse til underviser i dansk som andetsprog for voksne eller have tilsvarende kompetencer.

Inden for det ordinære uddannelsessystem undervises der også på Erhvervsuddannelserne i erhvervsrettet andetsprogsdansk, og social- og sundhedsuddannelser har deltaget i forskellige samarbejdsprojekter med blandt andet sprogcentre, fagforeninger, og kommuner med henblik på at få flere kvinder med indvandrerbaggrund ind på social- og sundhedsuddannelserne. Pædagog- og lærerseminarier har siden 1985 udbudt Forberedelseskursus for indvandrere og flygtninge.

Der anvendes hvert år mange ressourcer på særlige initiativer der skal bidrage til at styrke integrationen. De initiativtyper hvor der indgår elementer af voksenuddannelse, er primært initiativer der fokuserer på beskæftigelsesfremme, etablering af mentorordninger, kvinder, og styrkelse af medborgerskab. Ud over de positive erfaringer med at kombinere sprog og arbejde, er der ligeledes gode erfaringer med at lægge vægt på samarbejde og koordinering mellem flere grupper af aktører. Det kan dreje sig om virksomheder, sprogcentre, jobcentre, offentlige forvaltninger m.fl. Det er endvidere vigtigt at deltagerne har klare mål at arbejde henimod, og at der er en tydelig kobling mellem en bestemt branche eller virksomheds behov og tilrettelæggelsen af undervisningen.

Anvendelsen af online-undervisning er endnu ikke så udbredt, men det er et område der er i vækst, særligt i forbindelse med undervisning på Danskuddannelse 3. Undervisning online kan især bidrage til at undervisningen bliver mere fleksibel i tid og rum og derved være med til at gøre den mere tilgængelig for grupper der ellers kan have vanskeligt ved at følge undervisningen, blandt andet på grund af beskæftigelse og forpligtelser i hjemmet. 


\section{Indledning}

Denne rapport undersøger i hvor høj grad og hvordan voksen- og efteruddannelse anvendes i Danmark som led i arbejdet med at integrere indvandrere på arbejdsmarkedet.

Indvandrere omfatter i denne sammenhæng, og gennem hele rapporten, også flygtninge.

De tal der anvendes i rapporten, er alle hentet fra Danmarks Statistik; de sidste er hentet i oktober 2009. Tallene går derfor kun frem til 2007. Til trods for at der på nogle områder er nyere tal fra andre kilder, er det fravalgt at anvende disse med henblik på at sikre størst mulig konsistens og sammenlignelighed.

Efter et kort oprids af indvandringsmønsteret i Danmark bliver der i kapitel 2 redegjort for udviklingen i de nationale integrationsstrategier og -politikker. I kapital 3 bliver anvendelsen af voksen- og efteruddannelser i integrationsindsatsen beskrevet. Her indgår Danskuddannelsen, uddannelserne inden for voksen- og efteruddannelsessystemet, og også enkelte uddannelser inden for det ordinære uddannelsessystem i det omfang de er skønnet relevant ${ }^{1}$. Valget kan bygge på at mange voksne indvandrere de facto anvender en bestemt uddannelse, eller det kan bygge på at der i tilknytning til en uddannelse er ordninger der er særligt rettet mod (voksne) indvandrere. Endelig består kapitel 4 af en gennemgang af særlige integrationsinitiativer der omfatter voksen- og efteruddannelseselementer. Særlige initiativer er defineret som initiativer, der er tidsmæssigt og finansielt afgrænsede.

\footnotetext{
${ }^{1}$ Se bilag 1 for en skematisk oversigt over det danske uddannelsessystem
} 



\section{Indvandrere og efterkommere i Danmark}

Arbejdskraftindvandring og flygtninge

Indvandringsmønsteret i Danmark har skiftet gennem de sidste $40 \mathrm{år}^{2}$. Fra 1960'ernes arbejdskraftindvandring over stigende flygtningestrømme i løbet af 1980'erne og 1990'erne fra særligt Mellemøsten og i midten af 1990'erne fra det tidligere Jugoslavien, især Bosnien, til nu igen i stigende omfang at bestå af arbejdskraftindvandring. Arbejdskraftindvandringen kommer hovedsageligt fra EU-lande og er især steget siden Polen i 2004 blev medlem af EU; således kom der i 20075.597 personer fra Polen. Trods den stigende indvandring fra vestlige lande, er der fortsat flest indvandrere og efterkommere fra ikkevestlige lande. Det skyldes først og fremmest at indvandrere fra vestlige lande i vid udstrækning kommer til Danmark som led i uddannelse eller arbejde og genudvandrer i langt højere grad end indvandrere fra ikke-vestlige lande, der primært kommer til Danmark som flygtninge eller familiesammenførte.

Den 1. januar 2008 udgjorde indvandrere og efterkommere ${ }^{3}$ i alt 9,1 pct. af befolkningen. Indvandrere alene udgjorde 6,9 pct. af befolkningen, heraf kom knap to tredjedele (62,8 pct.) fra ikke-vestlige lande. Dermed er antallet af indvandrere fra ikke-vestlige lande femdoblet siden 1980. En tredjedel af alle indvandrere og godt to tredjedele (69 pct.) af alle efterkommere i Danmark havde den 1. januar 2008 dansk statsborgerskab. 1. januar 2007 var 30 pct. af

\footnotetext{
${ }^{2}$ Gennemgangen af indvandrere og efterkommere i Danmark bygger på oplysninger fra Indvandrere i Danmark 2008 (Danmarks Statistik 2008).

${ }^{3}$ Indvandrere defineres som personer der er født i udlandet af forældre hvor ingen af dem er danske statsborgere, eller født i Danmark. Efterkommere defineres som personer der er født i Danmark af forældre hvor ingen er danske statsborgere, eller født i Danmark. Personer med dansk oprindelse har mindst én forælder der både er dansk statsborger og født i Danmark.
} 
indvandrerne og 43 pct. af efterkommerne i Danmark flygtninge ${ }^{4}$. Stort set alle flygtninge (99 pct.) har oprindelse i Afrika, Asien eller europæiske lande uden for EU og Norden.

\section{Indvandrere og efterkommeres beskceftigelse}

Personer med dansk oprindelse har en betydeligt højere beskæftigelsesfrekvens end indvandrere fra ikke-vestlige lande. Således var 78,7 pct. af de 16-64-årige med dansk oprindelse i beskæftigelse den 1. januar 2007. Det tilsvarende tal for indvandrere fra ikke-vestlige lande var 53,4 pct., hvilket dog er en markant stigning i forhold til 1996 hvor andelen af beskæftigede blandt ikke-vestlige indvandrere kun var 33 pct. Særligt blandt kvindelige indvandrere fra ikke-vestlige lande er beskæftigelsesfrekvensen lav (46,2 pct.). Efterkommere har en højere beskæftigelsesfrekvens end indvandrere, men stadigt lavere end folk med dansk oprindelse.

Tabel 1.1. Beskæftigelsesfrekvens for 16-64-årige 2007

\begin{tabular}{lccccc}
\hline & Danskere & \multicolumn{2}{c}{ Indvandrere } & \multicolumn{2}{c}{ Efterkommere } \\
\cline { 2 - 6 } & & Ikke-vestlige & Vestlige & Ikke-vestlige & Vestlige \\
\hline \multirow{2}{*}{ Beskæftigelsesfrekvens } & $78,7 \%$ & $53,4 \%$ & $64,0 \%$ & $64,9 \%$ & $74,1 \%$ \\
\hline
\end{tabular}

Fra 1981 til 2007 har beskæftigelsesfrekvensen ligget stabilt på omkring 75 pct. for personer med dansk oprindelse. Frekvensen for vestlige indvandrere følger det samme mønster, men ligger 10-16 procentpoint lavere end for personer med dansk oprindelse. I modsætning hertil oplevede indvandrere fra ikke-vestlige lande et markant fald i beskæftigelsesfrekvensen i midten af 1990'erne fra 57 pct. i 1981 til 33 pct. i 1996. Dette skyldes ifølge Danmarks Statistik at gruppen af ikke-vestlige indvandrere voksede kraftigt i den periode, ikke mindst som følge af store flygtningestrømme fra det tidligere Jugoslavien. Generelt har flygtninge en lavere beskæftigelsesgrad end øvrige indvandrere.

\footnotetext{
${ }^{4}$ Flygtninge defineres som: 1) Indvandrere med kendt opholdsgrundlag som flygtninge, 2) børn af flygtninge, 3) personer med ukendt opholdsgrundlag som kommer fra et land der er klassificeret som flygtningeland i indvandringsåret. For indvandrere gælder at de selv er kommet til Danmark som flygtninge, mens efterkommere har mindst én forælder der er flygtning.
} 
Ikke-vestlige indvandrere er primært beskæftiget inden for brancherne hotel og restauration samt forretningsservice (herunder rengøring). Den igangværende arbejdskraftindvandring fra Polen består først og fremmest af mænd og er primært rettet mod forretningsservice, hvor næsten en femtedel (19,4 pct.) af de beskæftigede polakker er ansat, og mod bygge- og anlægsvirksomhed, hvor 17,3 pct. af de polske indvandrere i beskæftigelse er ansat. 



\section{Nationale integrationsstrategier}

Danmarks strategier og målsætninger på integrationsområdet har, siden den første integrationslov blev vedtaget i 1998, fokuseret på integration på arbejdsmarkedet. En opfattelse af sproget som en afgørende forudsætning for at kunne komme i beskæftigelse er blevet afløst af en opfattelse af at sproget læres bedst i forbindelse med arbejde, og med den nuværende regering er kravene til beskæftigelse blevet skærpet. Udviklingen bliver kort ridset op i det følgende. I bilag 1 findes en kronologisk oversigt over relevante strategier, grundlag, love og bekendtgørelser. En oversigt over centrale aktører findes i bilag 2 .

Vejen til Danmarks første integrationslov i 1998

I juli 1998 vedtog den daværende regering (den fjerde Nyrup-regering (1998-2001)) bestående af Socialdemokratiet (S) og Det Radikale Venstre (R) Danmarks første integrationslov, der trådte i kraft 1. januar 1999. Indtil da var integrationspolitikken reguleret via Udlændingeloven, som først og fremmest regulerer udlændinges adgang til og ophold i Danmark. Den politiske opmærksomhed blev første gang rettet mod integrationsspørgsmålet med den daværende socialdemokratiske regerings indvandrerpolitiske redegørelse i 1980, og med en skærpelse af Udlændingeloven i 1986 blev Danmark et af de vanskeligst tilgængelige europæiske lande for flygtninge, hvor det tidligere havde været et af de mest liberale lande (Hamburger 1997, www.denstoredansk.dk).

Forarbejdet til Integrationsloven blev lavet under den tredje Nyrupregering (1996-1998), og en hurtig vedtagelse af loven samt en ændring af Udlændingeloven blev indskrevet i regeringsgrundlaget „Godt på vej“ fra 1998. Baggrunden var at indvandrerdebatten fyldte stadigt mere i det politiske landskab. Efter den store flygtningestrøm fra især det tidligere Jugosla- 
vien og bekymringer om stigende ghettoisering i flere af de store byer ${ }^{5}$, blev indvandringen og antallet af udlændinge et vigtigt element i valgkampen i 1998. Dansk Folkeparti, der i høj grad fokuserede på at begrænse indvandringen, stillede op for første gang og stormede ind i Folketinget med 13 mandater. Der var således stor folkelig og politisk opmærksomhed omkring indvandringsspørgsmålet i sidste halvdel af 1990’erne og fokus på at forbedre integrationsindsatsen.

På den baggrund ønskede regeringen med Integrationsloven at koordinere den hidtil spredte integrationsindsats: Dansk Flygtningehjælp havde hidtil haft det generelle ansvar for det 18 måneder lange integrationsforløb for flygtninge, mens kommunerne havde været ansvarlige for bolig, og amterne for sprogundervisningen. Med Integrationsloven blev integrationsperioden forlænget til tre år, og det primære ansvar for forløbet blev placeret ved landets kommuner. Endvidere blev den såkaldte integrationsydelse indført. Der var tale om en særlig ydelse til flygtninge, som var betydeligt lavere (omkring 2000 dkr. lavere pr. måned) end den kontanthjælp danskere kunne få. Indførelsen af integrationsydelsen vakte stor debat, også internationalt, idet blandt andre UNHCR mente at ydelsen var diskriminerende. Efter nogle måneder valgte regeringen at ophæve integrationsydelsen.

Endnu en udløber af regeringens ønske om at skabe bedre muligheder for integration, var vedtagelsen af den første danskuddannelseslov ${ }^{6}$ der, som Integrationsloven, blev vedtaget i juli 1998 og trådte i kraft 1. januar 1999. Formålet med loven var at øge danskundervisningens kvalitet og effektivitet samt at øge samspillet mellem danskundervisningen og den øvrige integrations- og aktiveringsindsats. Dette søgte man at opnå ved hjælp af en centralisering af de afsluttende prøver og en formalisering af danskuddannelsen. Før lovens ikrafttræden havde der på mange sprogskoler udviklet sig en praksis for private prøver i tilknytning til den afsluttende undervisning. Det var sket på baggrund af kursisternes behov for at kunne dokumentere dansksproglig kompetence og sprogskolernes interesse i at synliggøre deres indsats og dokumentere deres resultater. Konsekvensen blev „,et kludetæppe af formelle krav til dansk“ (Lindberg 2000). Ud over de centrale prøver, som Undervisningsministeriet var ansvarlig for, blev der med loven indført obligatorisk

\footnotetext{
${ }^{5}$ Blandt andre Århus’ daværende socialdemokratiske borgmester, Thorkild Simonsen, udtrykte stigende bekymring for udviklingen i antallet af udlændinge efter at især borgmestre fra byer syd for København advarede mod ghettoisering (BT 2000)

${ }^{6}$ Lov om undervisning i dansk som andetsprog for voksne udlændinge m.fl. og sprogcentre (Undervisningsministeriet 1998)
} 
evaluering af kursisternes sproglige kompetencer, og det blev ekspliciteret at vejledning indgår som en central del af integrationsindsatsen.

Det helt overordnede mål med både Integrations- og Danskuddannelsesloven var således at samle ansvaret for integrationsopgaven og dermed skabe bedre grundlag for en helhedsorienteret indsats.

Nyt regeringsgrundlag 2001 - øget fokus på selvforsørgelse og deltagelse på arbejdsmarkedet. Integrationskontrakt og sanktioner

I november 2001 vandt Venstre (V) og Konservative (K) regeringsmagten. Dansk Folkeparti (DF) blev fra starten regeringens støtteparti. VKregeringens nye regeringsgrundlag lagde vægt på at „begrænse den nuværende tilstrømning af udlændinge der kommer til Danmark“ og sikre en „langt bedre integration af de indvandrere, som er i Danmark“ (Statsministeriet 2001). Bedre integration blev her defineret som at indvandrerne skulle lære dansk og i arbejde hurtigst muligt så de kunne blive selvforsørgende, frem for at modtage offentlig forsørgelse. Regeringen betragtede således „deltagelse på arbejdsmarkedet (som) et vigtigt bidrag til en bedre integration af udlændinge i det danske samfund“ (Statsministeriet 2001). Målene om sprog, arbejde og selvforsørgelse blev understreget igen i regeringens visionspapir „En ny udlændingepolitik“ fra januar 2002. Regeringen ønskede med egne ord at gøre op med „først lære dansk, så i arbejde“ og fokuserede på at danskundervisningen blev arbejdsrettet og aldrig må blokere for arbejde. Udover arbejde handler integration ifølge regeringen dog „også om at blive i stand til at deltage i andre af samfundslivets områder, således at den enkelte nye borger kan indgå aktivt i eksempelvis foreningsarbejde og skolebestyrelser“ (Regeringen 2002b, p. 1).

Med henblik på at bremse tilstrømningen af indvandrere ønskede regeringen endvidere at stramme Udlændingeloven. En af stramningerne var genindførelsen af introduktionsydelsen, der dog denne gang blev formuleret på en måde så den ikke formelt diskriminerer indvandrere, idet også danske borgere risikerer at blive omfattet af reglerne. Regeringens motivation for at indføre de lavere ydelser var en betragteligt lavere beskæftigelsesfrekvens blandt indvandrere end blandt oprindelige danskere. Desuden er det troen på at lavere velfærdsydelser kan fungere som økonomisk incitament til at blive mere aktivt arbejdssøgende. Regeringens støtteparti, DF, lagde dog ikke skjul på at formålet med stramningerne for dem også var at mindske Dan- 
marks tiltrækningskraft $\mathrm{i}$ forhold til potentielle nye indvandrere (www.denstoredanske.dk).

I forlængelse af ønsket om øget erhvervsretning og effektivisering af integrationsindsatsen generelt og Danskuddannelsen i særdeleshed, afløste VK-regeringen den hidtidige handlingsplan som indvandrerne skulle udarbejde som led i integrationsaftalen, med en integrationskontrakt. Det grundlæggende blev ikke ændret meget, og integrationskontrakten går i lighed med tidligere ud på at der udarbejdes et individuelt integrationsprogram der er afpasset i forhold til den enkeltes kvalifikationer og ressourcer, og som er målrettet mod arbejde eller uddannelse. I modsætning til den tidligere handlingsplan skal det dog af integrationskontrakten fremgå hvilke sanktioner der gælder, hvis udlændingen ikke opfylder kontrakten (Integrationsministeriet 2002) ${ }^{7}$. Ved fastlæggelse af integrationskontraktens indhold skal indvandrerens kompetencer, såvel formelle som uformelle, inddrages. Derfor indgår en afklaring af både faglige og personlige kompetencer som en integreret del af introduktionsprogrammet (Integrationsministeriet 2009g). Derudover foretages der individuel kompetencevurdering (IKV) i forbindelse med en række uddannelser inden for det formelle uddannelsessystem.

Frem til endnu en lovændring i 2003 (Integrationsministeriet 2003a og Integrationsministeriet 2003b) omfattede introduktionsprogrammet et særskilt kursus i samfundsforståelse. Fra 2003 blev det i stedet integreret i Danskuddannelsen, og desuden blev målet om hurtig beskæftigelse og selvforsørgelse skrevet ind i den nye Danskuddannelseslov. Samtidig fik sprogskolerne mulighed for at anvise job- og praktikpladser. Den mulighed blev åbnet for at bedre mulighederne for en koordineret indsats med bedre sammenhæng mellem sprogundervisning og adgang til arbejdsmarkedet. Derudover blev der med den nye danskuddannelseslov indført en begrænsning i uddannelsesretten på tre år ${ }^{8}$. Herefter har indvandrere kun ret til danskuddannelse i tre år fra det tidspunkt, hvor de kan påbegynde en danskuddannelse. De har således ikke ret til danskuddannelse efter de tre år, heller ikke hvis de - f.eks. på grund af arbejde - ikke har kunnet modtage undervisning,

\footnotetext{
${ }^{7}$ Der er tale om økonomiske sanktioner i form af reduktion i introduktionsydelsen.

${ }^{8}$ Kommunerne har dog pligt til at forlænge uddannelsesretten hvis udlændingen f.eks. på grund af sygdom eller barsel har været afskåret fra at følge danskuddannelse. Kommunerne har kun pligt til at forlænge perioden hvis der foreligger særlige forhold ud over beskæftigelse. Kommunerne har altid mulighed for at forlænge perioden. Det varierer meget fra kommune til kommune i hvilket omfang denne mulighed benyttes.
} 
eller hvis de af andre grunde kun har kunnet modtage undervisning i begrænset omfang i de første tre år (Integrationsministeriet 2003a) ${ }^{9}$

Indførelsen af individuelle kontrakter og eksplicitte sanktioner hænger nøje sammen med regeringens „Vision og strategier for en bedre integration“, som en ministergruppe udarbejdede i juni 2003 på baggrund af regeringsgrundlaget fra 2001. Herefter hviler integrationspolitikken på fire grundlæggende principper: 1) vi skal give plads til forskelligheden og lære at drage fordel af den, 2) vi skal gøre op med klientgørelsen og vise respekt ved at stille krav, 3) vi skal gøre op med konsekvensløsheden i alle dens former og 4) vi skal ikke undskylde undertrykkende familiemønstre med „kultur“ (Regeringen 2003). Heri definerer regeringen også hvad de forstå ved ,vore værdier“: „Der tænkes på det grundlæggende frisind, der udspringer af respekt for andre mennesker og det enkelte menneskes særpræg. Og der tænkes på vort demokratibegreb, som vel at mærke indeholder andet og mere end flertalsstyre: Krænkelser af menneskerettighederne bliver ikke bedre af at være vedtaget af et flertal - derfor har vi grundlove og internationale konventioner. Disse værdier skal nyankomne lære at kende, og der skal stilles krav om, at værdierne bliver respekteret“ (Regeringen 2003).

Endnu engang understreges vigtigheden af at indvandrere får bedre danskkundskaber - både fordi det øger mulighederne for at deltage som aktiv medborger, og fordi det er vigtigt for at komme ind på arbejdsmarkedet - dette med henblik på såvel selvforsørgelse som muligheden for at „bidrage til en positiv samfundsudvikling“" (Regeringen 2003).

Nyt regeringsgrundlag 2005 - generel fokus på øget beskcftigelse.

Resultatstyring og kontrakterklcring

I 2005 var der igen folketingsvalg, hvilket ikke ændrede regeringen, der fortsat bestod af $\mathrm{V}$ og $\mathrm{K}$. I forbindelse med valget udarbejdede de dog et nyt regeringsgrundlag „Nye mål“ i februar 2005. I forhold til indvandrer- og integrationspolitikken er det centrale i „Nye mål, at regeringen fokuserer på at øge beskæftigelsen generelt og har en en målsætning om at få 25.000 flere indvandrere i arbejde frem mod 2010. Opkvalificering bliver i den forbindelse betragtet som et helt centralt aspekt - $\mathrm{i}$ forhold til indvandrere er det deres „grundlæggende kvalifikationer, herunder særligt danskkundskaber, (der)

\footnotetext{
${ }^{9}$ Kommunerne kan udvide retten. Det er meget forskelligt i hvor stort omfang kommunerne anvender den mulighed.
} 
skal styrkes“ (Regeringen 2005a), ligesom blandt andet brugen af mentorordninger skal øges.

På baggrund af blandt andet målet om at få yderligere 25.000 indvandrere i beskæftigelse, udarbejdede regeringen i maj 2005 integrationsplanen „En ny chance til alle“. Heri understreges VK-regeringens hidtidige linje, der blandt andet omfatter øget krav om selvforsørgelse, og på baggrund af det nye regeringsgrundlag er der et forstærket fokus på beskæftigelse. Regeringen understreger derudover kommunernes rolle i integrationsindsatsen og introducerer en ny økonomisk incitamentsstruktur der har til hensigt at få kommunerne til „at gøre en ekstra indsats“ (Regeringen 2005b). Refusionssystemet skal således fremover bygges op så der er en klar sammenhæng mellem tilskud og refusioner på den ene side og indsats og resultater på den anden.

Integrationsplanen blev efterfølgende udmøntet yderligere i ,aftale om „En ny chance til alle“, som regeringen indgik med DF og S. Det afgørende nye i aftalen var indførelsen af en kontrakterklæring om „,integration og aktivt medborgerskab i det danske samfund“, som alle udlændinge skal underskrive, idet de hermed „viser vilje til integration“ (Regeringen 2005b). Af kontrakterklæringen fremgår blandt andet at udlændingen „vil respektere samfundets grundlæggende værdier. For eksempel at de vil overholde straffelovens regler. At de vil arbejde for deres børns integration - ikke mindst ved at sikre børnene skolegang. Og at de vil respektere det enkelte menneskes frihed og integritet samt ligestilling mellem kønnene“ (Regeringen 2005b). Kontrakterklæringen blev gennemført med en ændring af Integrationsloven i 2006 (Integrationsministeriet 2006b).

Der tegner sig et skifte i hovedfokus fra 1999 til 2004. Hvor hovedformålet med Danskuddannelsesloven i 1999 var at give Danskuddannelsen et kvalitetsløft, er der fra 2004 kommet større fokus på integration på arbejdsmarkedet, og resultatstyring er blevet indført. Den samme tendens gør sig gældende i den generelle integrationsindsats, hvor der ses en bevægelse fra aktivitetsbaseret til resultatbaseret finansiering (Rambøll 2007, p. 2ff). De overordnede ønsker om at begrænse indvandringen og forbedre integrationen forstået som arbejde og selvforsørgelse, samt ønsket om en „effektivisering“ af danskundervisningen har været kendetegnende for integrationspolitikken i hele VK-regeringsperioden fra 2001 til i dag. 
Voksen- og efteruddannelsessystemets rolle. Livslang lering og samarbejde mellem aktører

Voksen- og efteruddannelsessystemet anvendes i langt overvejende grad i forhold til beskæftigelsesaspektet i integrationsindsatsen. Medborgerskab understreges dog også som et vigtigt led i integrationen.

På det mere overordnede voksen- og efteruddannelsesområde vedtog regeringen i 2006 globaliseringsstrategien „Fremgang, fornyelse og tryghed“, der blandt andet fastsætter målet om at „alle skal uddanne sig hele livet“. I den forbindelse skal voksen- og efteruddannelserne styrkes, og der lægges op til „,målrettede og attraktive tilbud, så flere voksne med svage eller snævre kompetencer kommer i gang“. Målet er at gøre voksen- og efteruddannelsesindsatsen „effektiv og fleksibel“ og sikre at den understøtter gode jobmuligheder for den enkelte (Regeringen 2006a). Strategien på voksen- og efteruddannelsesområdet følger dermed tendensen fra integrationsindsatsen med fokus på effektivitet, fleksibilitet og arbejdsmarkedets behov. I forhold til indvandrere lægges der op til at „der skal udvikles supplerende tilbud i arbejdsmarkedsdansk i danskuddannelsessystemet og målrettede tilbud i almen voksenuddannelse og arbejdsmarkedsuddannelser“ (Regeringen 2006a). Målene gentages i Danmarks „Strategi for livslang læring“ som regeringen udarbejdede i april 2007 med udgangspunkt i globaliseringsstrategien (Jørgensen 2007).

I „Aftale om fremtidens velstand og velfærd og investeringer i fremtiden“ (Regeringen 2006b), som regeringen indgik i 2006 sammen med DF, S og R, fokuseres der igen på at få flere indvandrere og efterkommere i arbejde og på at styrke indsatsen for at få flere indvandrere i arbejde. Som centralt redskab nævnes nye firepartsaftaler ${ }^{10}$, en understregning af at regeringen betragter beskæftigelses- og integrationsindsatsen som et fælles ansvar hvor arbejdsmarkedets parter har en central rolle.

I 2007 trådte lov om „Udbygning af anerkendelse af realkompetence på voksen- og efteruddannelsesområdet mv. “i kraft. Loven udsprang af et politisk ønske om at øge mulighederne for anerkendelse af realkompetencer, og med den bliver det fastslået at voksenuddannelsescentre og andre uddannelsesinstitutioner der udbyder almen voksenuddannelse har pligt til at tilbyde individuel kompetencevurdering (IKV) (Undervisningsministeriet 2007g).

\footnotetext{
${ }^{10}$ Aftale mellem regeringen, kommunerne og arbejdsmarkedets parter.
} 
Fremadrettet. Fokus på arbejdskraftindvandring og revision af Danskuddannelsesloven

I efteråret 2009 har Integrationsministeren fremsat forslag til ændring af Danskuddannelsesloven. Forslaget bygger blandt andet på anbefalinger fra en arbejdsgruppe nedsat af regeringen. Anbefalingerne omfatter blandt andet etableringen af et nyt fleksibelt danskundervisningstilbud, „intro-dansk“, for udenlandske arbejdstagere. Tilbuddet skal rettes mod udlændinge der er kommet til Danmark for at arbejde, og som man forventer kun vil være i landet midlertidigt. Intro-dansk er således tænkt som et begynderkursus møntet på beskæftigede udlændinge som kan tilrettelægges arbejdsmarkedsrettet. Derudover anbefaler arbejdsgruppen fremrykning af begyndelsestidspunkt for danskuddannelse således at alle udenlandske arbejdstagere har adgang til danskuddannelse når de har lovligt ophold i Danmark. De anbefaler endvidere en ændring af den tre-årige uddannelsesret til en klippekortsmodel, der skal kunne benyttes inden for fem år. Det understreges at klippekortsmodellen ,,... alene (tager) sigte på at give et mere fleksibelt tilbud til personer i beskæftigelse eller personer med særlige indlæringsproblemer. Sigtet med det tre-årige introduktionsprogram - at sikre hurtigst mulig selvforsørgelse og gennemførelse af danskuddannelse - fastholdes. "Endelig omfatter anbefalingerne at de individuelle læringsplaner afskaffes som obligatoriske for så vidt angår kursister med „et normalt progressionsmønster“, mens de foreslås fastholdt for kursister der har „,æærlige vanskeligheder med danskindlæringen og langsom progression“ (Lou 2009). I lovforslaget, som det er fremsat i august 2009, indgår ikke en ændring af uddannelsesretten til en klippekortsmodel. Anbefalingerne om at indføre Intro-dansk er blevet fulgt.

En hovedmålsætning i den danske integrationspolitik har i hele den gennemgåede periode været at indvandrere skal hurtigst muligt i beskæftigelse. Fra at se sproget som det primære er der i dag et øget fokus på deltagelse på arbejdsmarkedet som det primære. Midlerne hertil er blevet skærpet i perioden. Ansvaret for integrationsindsatsen er entydigt placeret ved kommunerne. Danskundervisningen, der oprindeligt var decentral, er blevet formaliseret og centraliseret med centrale læseplaner, modultest og prøver. Den oprindelige integrationslov bestemte at der skulle udarbejdes en handlingsplan for indvandrerens uddannelse og beskæftigelse; den er siden blevet erstattet af en integrationskontrakt med angivelse af eksplicitte sanktioner ved manglende overholdelse, og den er yderligere blevet suppleret med en integrationserklæring, hvor indvandreren skal skrive under på at ville arbejde for at 
forstå „det danske samfunds grundlæggende værdier og normer“. Styringen og finansieringen har udviklet sig fra at være aktivitetsbaseret til at være resultatbaseret både i forhold til danskuddannelsen og i forhold til den samlede integrationsindsats. Samtidig har man forsøgt at åbne muligheder for en mere helhedsorienteret indsats ved blandt andet at give sprogskolerne mulighed for at anvise job- og praktikpladser. 



\section{Initiativer til styrkelse af integration gennem ordinær voksen- og efteruddannelse}

\subsection{Beskrivelse af voksen- og efteruddannelsessystemet}

Det danske uddannelsessystem kan overordnet deles i tre grupper: 1) det ordinære system, som betegner folkeskolen, de gymnasiale uddannelser, erhvervsuddannelserne, de korte, mellemlange og lange videregående uddannelser, 2) voksen- og efteruddannelsessystemet, hvorunder hører uddannelser rettet mod voksne som samlet dækker de samme niveauer som det ordinære system, og 3) det uformelle system, folkeoplysning, herunder højskoler.

Her fokuseres især på uddannelserne inden for voksen- og efteruddannelsessystemet, men også uddannelser inden for det ordinære uddannelsessystem vil blive beskrevet hvor det er relevant, enten på grund af stor søgning fra indvandrere, eller fordi der er ordninger rettet mod indvandrere i tilknytning til uddannelsen. Endelig vil folkeoplysningsforbundenes bidrag til integrationen af voksne indvandrere blive beskrevet kort. I rapporten anvendes betegnelsen „det ordinære uddannelsessystem“ eller „ordinære uddannelser“ om alle de tre grupper af uddannelser der beskrives i dette afsnit.

Styringen af voksen- og efteruddannelserne sker ved love og bekendtgørelser. Arbejdsmarkedsuddannelserne (AMU), Voksen erhvervsuddannelserne (VEUD) og Grundlæggende voksenuddannelse (GVU) er tillige kendetegnet ved at arbejdsmarkedets parter har en central rolle i udviklingen af konkrete uddannelser. Ordningerne finansieres ved taxametertilskud fra staten og ved brugerbetaling (Finansministeriet 2006a). 


\subsection{Integrationsaktiviteter inden for voksen- og efteruddannelserne}

\subsubsection{Danskuddannelsen}

Danskuddannelsen består af tre del-uddannelser, målrettet hver sin gruppe af indvandrere, alt efter deres skole- og uddannelsesmæssige baggrund ${ }^{11}$. Hovedformålet med uddannelsen er ,at bidrage til, at voksne udlændinge med udgangspunkt i deres individuelle forudsætninger og integrationsmål ${ }^{12}$ opnår nødvendige dansksproglige kompetencer og viden om kultur- og samfundsforhold i Danmark, så de kan blive deltagende og ydende medborgere på lige fod med samfundets øvrige borgere.“ Den skal „bidrage til, at voksne udlændinge så hurtigt som muligt efter at have fået opholdstilladelse i Danmark tilegner sig færdigheder $\mathrm{i}$ at forstå og anvende det danske sprog og opnå kendskab til det danske arbejdsmarked, så de herved får mulighed for at komme i beskæftigelse og bliver i stand til at forsørge sig selv.“ Endelig skal danskuddannelsen „fremme voksne udlændinges aktive brug af det danske sprog samt bidrage til, at de opnår almene kundskaber og færdigheder, som er relevante i forhold til arbejde og uddannelse samt livet som medborger i et demokratisk samfund.“ (Integrationsministeriet 2006a).

Ud over de overordnede formål om at sikre kompetencer til beskæftigelse og selvforsørgelse samt kompetencer til aktiv brug af det danske sprog og evne til at deltage aktivt i det danske samfund, kvalificerer danskuddannelsen til videre uddannelse. Målet med Danskuddannelse 1 er primært at indvandrerne kan „varetage et ufaglært job og virke aktivt som borgere i samfundet“, mens målet med Danskuddannelse 2 er at indvandrerne kan deltage i kompetencegivende AMU-kurser (ArbejdsMarkedsUddannelser målrettet faglærte og ufaglærte) og lignende samt i erhvervsuddannelser, herunder sosu-uddannelserne (social- og sundhedsuddannelserne). Prøve i Dansk 2,

\footnotetext{
${ }^{11}$ Danskuddannelsen er således delt op i Danskuddannelse 1, 2 og 3. Danskuddannelse 1 er rettet mod kursister som ikke kan læse eller skrive på deres modersmål, eller som ikke kender det latinske alfabet. Danskuddannelse 2 er for kursister som har en kort skole- og uddannelsesbaggrund fra hjemlandet, og som „må forventes at have en forholdsvis langsom indlæring af dansk som andetsprog“. Danskuddannelse 3 er målrettet kursister med „en mellemlang eller lang skoleog uddannelsesbaggrund (...) og må forventes at have en forholdsvis hurtig indlæring af dansk som andetsprog“ Integrationsministeriet 2006. „Bekendtgørelse af lov om danskuddannelse til voksne udlændinge m.fl.“ Ministeriet for flygtninge, indvandrere og integration.

${ }^{12}$ Integrationsmål referer til de mål der defineres i hver enkelt indvandrers „integrationskontrakt“. Denne er beskrevet kort i kapitel 1.
} 
som afslutter Danskuddannelse 2, er ligeledes forudsætning for at opnå varig opholdstilladelse ${ }^{13}$. Danskuddannelse 3 sigter mod ,at kursisterne skal kunne få et job eller tage fortsat uddannelse“. Danskuddannelse 3 kan afsluttes efter modul 5 med Prøve i Dansk 3 og efter modul 6 med Studieprøven. Prøve i Dansk 3 (eller tilsvarende dokumenterede dansksproglige kompetencer) er en forudsætning for at opnå dansk statsborgerskab ${ }^{14}$, mens Studieprøven er det dansksproglige adgangsgrundlag til de videregående uddannelser (Bruun 2006). Alle de tre danskuddannelser er endvidere opbygget $\mathrm{i}$ moduler som alle afsluttes med en test.

I 2003 blev den oprindelige danskuddannelseslov fra 1998 ændret, primært med henblik på øget erhvervs- og arbejdsmarkedsretning af uddannelsen og på at gøre uddannelsen mere omkostningseffektiv i form af hurtigere gennemførelse. Den hurtigere gennemførelse måtte dog ifølge Integrationsministeriet ikke ske på bekostning af det kvalitetsløft uddannelsen fik med loven i $1998^{15}$ (Integrationsministeriet 2003a; Rambøll 2007; Undervisningsministeriet 1998). For at nå målene fokuseres der i den reviderede danskuddannelseslov og integrationslov på en høj grad af tidsmæssig og geografisk fleksibilitet, samspil med arbejdsmarkedet, individualiseret undervisning samt tidsmæssige begrænsninger og økonomiske incitamenter i form af taxameterstyring og lavere integrationsydelse.

\section{Danskuddannelsens effekter}

Helt overordnet konkluderer Rambøll i deres evaluering af implementeringen danskuddannelsesloven i forhold til Danskuddannelse 1 og Danskuddannelse 2 (Rambøll 2007) at den både bidrager til at indvandrerne kommer i arbejde eller uddannelse og til et aktivt medborgerskab i Danmark. Rambølls evaluering bygger på en undersøgelse med deltagelse af i alt fem uddannelsesinstitutioner og otte virksomheder. Undersøgelsen er i det følgende suppleret med yderligere undersøgelser hvor det har været muligt.

\footnotetext{
${ }^{13}$ Ubegrænset ophold kan også opnås ved Prøve i Dansk 1 samt engelskprøve svarende til niveauet for Prøve i Dansk 2.

${ }^{14}$ Udover at bestå Prøve i Dansk 3 med karakteren 4, er der krav om at indvandreren består en indfødsretsprøve og underskriver „erklæring om integration og aktivt medborgerskab i det danske samfund“.

${ }^{15}$ I 1998 vedtog Folketinget den første danskuddannelseslov, Lov om undervisning i dansk som andetsprog for voksne udlænding m.fl. og sprogcentre. Lovens hovedformål var at løfte kvaliteten af danskundervisningen, først og fremmest ved at centralisere og formalisere undervisningen i form af centrale læseplaner og prøver. Formålet med loven er kort beskrevet i kapitel 1.
} 


\section{Danskuddannelsens effekt med hensyn til arbejde og selvforsørgelse}

Flere virksomheder giver udtryk for en formodning om at indvandrerne lærer hurtigere, bedre og mere relevant dansk hvis danskuddannelse kombineres med arbejde og/eller praktik (Rambøll 2007). Også indvandrerne mener at danskuddannelsen hjælper i forhold til at finde arbejde. Således mener 58,1 pct. at uddannelsen i høj eller meget høj grad har sat dem i stand til at „læse og forstå en jobannonce“, og 49 pct. at den har sat dem i stand til „at klare en jobsamtale“. Det er i højere grad indvandrere der har fulgt Danskuddannelse 2, end dem der har fulgt Danskuddannelse 1, der har en positiv vurdering af uddannelsens effekt med hensyn til at finde arbejde. Blandt de kursister der er i arbejde, vurderer mere end 90 pct. at de i høj eller nogen grad er i stand til at tale med kolleger på en dansk arbejdsplads, og over 85 pct. oplever at de er i stand til at klare sig på lige fod med andre medarbejdere (Rambøll 2007, p. 66).

Oplevelsen af at indvandrere er i stand til at føre hverdagssamtaler, deles dog ikke af virksomhederne, der efterlyser at indvandrerne skal være bedre forberedt til netop det. Virksomhederne roser dog indvandrernes evne til at begå sig på en dansk arbejdsplads, idet de udtrykker tilfredshed med ,kursisternes forståelse af danske arbejdspladser og dansk arbejdspladskultur“ (Rambøll 2007, p. 77).

Udbyderne af Danskuddannelsen arbejder kontinuerligt med at udvikle arbejdsmarkedsrettede undervisningsforløb. De samarbejder i den forbindelse med virksomheder, fagforeninger og stat/kommuner (særligt jobcentre) med henblik på at lave integrerede forløb og generelt sikre at uddannelsen har en sammenhæng med arbejdsmarkedet. Initiativerne er meget forskelligartede og retter sig mod forskellige grupper af kursister. Projekttyperne og deres effekt beskrives i kapitel 4.

Ud over øget fokus på praktik oplever danskudbyderne også at der er kommet yderligere fokus på , arbejdspladsdansk“ i undervisningen. Integrationsministeriet har ydet tilskud til kurser i arbejdsmarkedsdansk ${ }^{16}$. En gennemgang af sprogudbydernes udbud viser dog at kun cirka hver syvende danskudbyder udbyder kurser i arbejdsmarkedsdansk. Langt de fleste tilbyder dog særligt tilrettelagte forløb i samarbejde med kommuner og/eller virksomheder.

Ifølge Rambøll giver enkelte virksomheder udtryk for at de oplever at praktikophold bliver taget mere seriøst af udbyderne end det var tilfældet før

\footnotetext{
${ }^{16}$ Læs nærmere om de særlige tiltag i kapitel 4.
} 
den nye danskuddannelseslov. Nogle udbydere oplever at praktikkerne er vigtige dels for indvandrernes motivation til at finde arbejde, dels i forhold til at styrke samarbejdet med erhvervslivet. De giver dog udtryk for at der har været et fald i antallet af praktikker fra 2007 til 2008, men forklarer faldet med at flere kursister har været i arbejde og dermed ikke har haft behov for at komme i praktik (se for eksempel Ballerup 2009).

Udbyderne er meget fleksible i forhold til både arbejdsgivernes og indvandrernes behov med hensyn til at tilbyde aften- og weekendundervisning. Ønsket om at være fleksibel i forhold til den tidsmæssige placering af undervisningen, var vanskeliggjort af et faldende kursisttal fra 2005 og frem (Rambøll 2007, p. 79; Integrationsministeriet 2008c, p. 3) ${ }^{17}$. De sidste par år har udbyderne dog oplevet en stigning i kursisttallet, særligt som følge af de seneste års øgede arbejdskraftindvandring. En gennemgang af danskudbydernes aktiviteter fra 2008 viser da også en stigning i antallet og andelen af kursister der modtager undervisning om aftenen og på lørdage (Ballerup Sprogcenter 2009; IA Sprog 2008; Sprogcenter Nordsjælland 2008; Sprogcenter Vejle 2008). En tendens der bekræftes af Poul Neergaard, formand for Foreningen af Ledere ved Danskuddannelser. Tendensen tyder på at flere kursister er i arbejde. Fokus på en tidsmæssigt fleksibel undervisning afspejler sig også i at næsten halvdelen af udbyderne tilbyder danskuddannelse som online kurser. Det er primært Danskuddannelse 3 for de bedst uddannede der har det tilbud, men der er også forsøg i gang på Danskuddannelse 2, netop i samarbejde med virksomheder (IA Sprog 2008). Deloitte konkluderer i deres undersøgelse fra 2007 at „fleksibiliteten kan konkluderes at være tilgodeset, idet udbyderne løbende tilpasser deres organisering og undervisningsform“ til virksomhedernes behov (Deloitte 2007, p. 10).

Den geografiske fleksibilitet i form af virksomhedsforlagt undervisning anvendes ikke i samme grad som den tidsmæssige fleksibilitet. Danskudbydere nævner at det kan være besværligt at gennemføre virksomhedsforlagt undervisning fordi nogle af de færdigheder der testes i modultestene, er svære at integrere her ${ }^{18}$. Dermed kan virksomhedsforlagt undervisning ifølge Rambøll (2007) øge gennemførelsestiden. Samlet vurderer Rambøll i deres undersøgelse at samspillet med arbejdsmarkedet gennem projekter og virk-

\footnotetext{
${ }^{17}$ I 2004 gik 5.600 og 14.357 kursister på henholdsvis Danskuddannelse 1 og 2; i 2005 var der henholdsvis 5.297 og 14.657 og i 2006 henholdsvis 4.491 og 11.726 (Integrationsministeriet 2008, p. 3).

${ }^{18}$ Ifølge Integrationsministeriet tester modultestene primært det almene sprog ud fra en betragtning om, at sproget på en arbjedsplads primært er alment dansk.
} 
somhedsforlagt undervisning er stagneret eller faldet efter indførelsen af den reviderede danskuddannelseslov i 2004 (Rambøll 2007, p. 87f) ${ }^{19}$.

Det er vanskeligt at sige noget entydigt om hvorvidt danskuddannelseslovens målsætning om at sikre at indvandrerne opnår beskæftigelse, er opfyldt, og det kan ikke afgøres i hvor høj grad arbejdsmarkedstilknytningen kan tilskrives Danskuddannelsen, konjunkturforhold eller ændret indvandringsmønster.

\section{Danskuddannelsens effekt med hensyn til videre uddannelse}

Danskuddannelse 1 er som nævnt rettet mod indvandrere uden skolebaggrund og har på den baggrund ikke en målsætning om at kvalificere deltagerne til videre uddannelse. Det har både Danskuddannelse 2 og 3, der har som målsætning at kvalificere til kompetencegivende AMU-kurser og lignende erhvervsuddannelser henholdsvis videre uddannelse.

Ifølge Rambølls undersøgelse er det kun en tredjedel af indvandrerne der mener at Danskuddannelsen har sat dem i stand til ,at finde ud af hvilke uddannelsesmuligheder de har“. Under halvdelen (46,8 pct.) oplever at de i høj eller nogen grad kan følge med i undervisningen, og mindre end en tredjedel (32,2 pct.) oplever at de kan tale med deres medstuderende (Rambøll 2007, p. 66). Det er vigtigt at understrege at tallene gælder for indvandrere der har fulgt Danskuddannelse 1 og 2, men ikke Danskuddannelse 3.

Lund og Bertelsen foretog i 2008 kvalitative sprogbehovsanalyser på de videregående uddannelser i forhold til studerende med Studieprøven som sproglig kompetence. Studieprøven skal sikre det dansksproglige niveau der er nødvendigt for at følge en videregående uddannelse. Lund og Bertelsen konkluderer imidlertid at studerende som har bestået Studieprøven „ikke er garanteret de nødvendige og tilstrækkelige kompetencer til at kunne deltage aktivt i kommunikationskomplekse aktivitetstyper som f.eks. forelæsningen, holdundervisningen, gruppearbejdet og fremlæggelsen“ (Lund og Bertelsen 2008, pp. 18f). Disse konklusioner understøttes endvidere af Rambølls undersøgelse fra 2007, der blandt andet peger på at uddannelsesinstitutionerne oplever at det er et problem at få indvandrere fra Danskuddannelsen til at „tage ansvar for egen læring, at deltage i projektarbejde og gruppearbejde etc.“ (Rambøll 2007, p. 77). Der bliver dog også givet udtryk for at deres studiekompetencer er blevet meget bedre end tidligere, en udvikling der

\footnotetext{
${ }^{19}$ Det tyder dog på at etableringen af puljen „Grundkursus i Arbejdsmarkedsdansk“ i 2007, har haft positiv betydning for omfanget af virksomhedsforlagt undervisning. Se endvidere kapitel 4 .
} 
ifølge Rambøll indicerer at nogle udbydere er blevet mere opmærksomme på at lære kursisterne en studieadfærd der passer til kravene i det danske uddannelsessystem.

Hvor virksomhederne efterlyser bedre forberedelse til at føre hverdagssamtaler, mener uddannelsesinstitutionerne at det daglige sprog er udmærket, men at der mangler dybde (Rambøll 2007, p. 76). Hverken uddannelsesinstitutioner eller indvandrerne selv mener altså at de opnår tilstrækkelige kompetencer på Danskuddannelsen til at kunne begå sig på lige fod med de øvrige kursister og studerende i det videre uddannelsessystem. Også ifølge Lund og Bertelsens analyse, vil studerende der har Studieprøven som forudsætning, mangle tilstrækkeligt komplekse og fagligt relevante sprogkompetencer til at kunne følge en videregående uddannelse på lige fod med danske medstuderende (Lund og Bertelsen 2008).

\section{Danskuddannelsens effekt med hensyn til dansksproglige kompetencer}

Det er et selvstændigt mål med Danskuddannelsen at kvalificere indvandrernes ,dansksproglige kompetencer“. Hvorvidt det er opnået, vurderes i Rambølls evaluering ud fra fire dimensioner: 1) i hvilken udstrækning indvandrerne taler dansk med familie og venner, 2) om de taler dansk i forbindelse med arbejde og praktik, 3) om de er i gang med uddannelse, og 4) om de bruger sproget i forbindelse med indkøb. En stor del af indvandrerne bruger dansk „sagligt“ på alle fire dimensioner. Anvendelsen af dansk er på alle dimensionerne højere for indvandrere der er under uddannelse eller i arbejde, end for indvandrere der ikke er (Rambøll 2007, p. 69).

\section{Effektivitet /gennemførselsstid på Danskuddannelsen}

Som nævnt ovenfor, var et af hovedformålene med den nye danskuddannelseslov der trådte i kraft i 2004, at øge Danskuddannelsens omkostningseffektivitet. Det skulle primært ske ved at øge gennemløbshastigheden. Det primære redskab hertil er indførelsen af taxameterstyring gennem modultakstsystemet. De tre danskuddannelser er hver opdelt i seks moduler, og udbyderne betales i forhold til hvor mange kursister der består hvert modul, og de belønnes derved for hurtigt at få så mange som muligt gennem uddannelsen. Med det formål at give indvandrerne incitament til hurtigere at gennemføre Danskuddannelsen, er retten til at følge danskuddannelsen begrænset til tre år, uafhængigt af hvor mange timer man har modtaget undervisning i løbet af de tre år. 
Ifølge både Rambøll (2007) og Deloitte (2007) tyder det på at det er lykkedes at øge omkostningseffektiviteten i form af hurtigere gennemførsel af Danskuddannelsen. Leif Husted (2008) har lavet en undersøgelse af gennemførselshastigheden på Danskuddannelsen fra 2004-2006 og konkluderer at der anvendes færre undervisningstimer på at nå et givet kompetenceniveau end under den forrige lov. Det kan imidlertid ikke afgøres „om det alene er de nye instrumenter og rammer“ der er årsag til udviklingen (Husted 2008, p. 9). Den hurtigere gennemførsel kan også i et vist omfang forklares af den ændrede kursistsammensætning, der i stigende grad udgøres af vestlige indvandrere der generelt har en længere skole- og uddannelsesbaggrund og kommer med modersmål der ofte ligger tættere på dansk. Samlet lader det til at modultakstsystemet har bidraget til en hurtigere gennemløbshastighed og dermed øget omkostningseffektivitet.

Ifølge Rambøll vurderer flere lærere i deres undersøgelse ${ }^{20}$, „, at flere kursister i dag er dårligere til dansk, når de afslutter en uddannelse, end det var tilfældet før lovændringen“ (Rambøll 2007, p. 83). Det har ifølge lærerne betydet at tid til fordybelse og tilegnelse af et bredere og mere velfunderet sprog forsvinder, som følge af en øget fokusering på hurtigst muligt at bestå den næste test. De frygter at for mange af indvandrerne kommer igennem uddannelsen med præcis det minimum af kompetencer der skal til for at bestå, men uden at blive tilstrækkeligt gode til dansk (Rambøll 2007, p. 39).

Udbydere frygter endvidere at stramningen af uddannelsesretten til tre år vil medføre at de svageste indvandrere ikke gennemfører deres danskuddannelse ${ }^{21}$. Treårs-reglen kan også få negative konsekvenser for indvandrere i arbejde. De der har arbejde, er i vidt omfang henvist til aftenundervisning, og de får kun et begrænset antal undervisningstimer. Frygten går endvidere på at indvandrere der rammes af arbejdsløshed, ikke har oparbejdet de nødvendige sproglige forudsætninger til at blive omskolet eller tage en uddannelse (Rambøll 2007, p. 40).

\section{Folkeoplysningsforbundenes rolle}

Undervisningen i dansk som andetsprog for voksne er i en del tilfælde placeret på daghøjskoler, oplysningsforbund og ungdomsskoler. Derudover spiller oplysningsforbundene - både daghøjskoler, oplysningsforbund og aftensko-

\footnotetext{
${ }^{20}$ Som nævnt p. 21, bygger Rambølls evaluering på en undersøgelse med deltagelse af i alt fem uddannelsesinstitutioner og otte virksomheder

${ }^{21}$ Der er i loven mulighed for at kommunerne kan udvide de tre års uddannelsesret; det er meget forskelligt i hvilket omfang den mulighed anvendes.
} 
ler - flere steder en aktiv rolle i forbindelse med jobintroducerende kurser og kulturarrangementer ${ }^{22}$. Ofte foregår arrangementerne og sprogundervisningen i samarbejde med andre aktører i lokalområdet ${ }^{23}$. Den øgede fokus på anerkendelse af realkompetencer som „realkompetenceloven“ fra 2007 (Undervisningsministeriet 2007g) er udtryk for, betyder også at undervisning inden for folkeoplysningen i højere grad end tidligere kan anvendes i det formelle uddannelsessystem.

\subsubsection{Almene og forberedende voksenuddannelser}

Der findes en række voksen- og efteruddannelser der sigter mod almen dannelse og på at give voksne kompetencer til at gå videre i uddannelsessystemet. De uddannelser det er relevant at kigge på her i forhold til integration af indvandrere, er almen voksenuddannelse (AVU), forberedende voksenuddannelse (FVU) og HF-enkeltfag (Højere Forberedelseseksamen). De tre uddannelser udbydes primært på voksenuddannelsescentre (VUC), men kan også i følges på daghøjskoler m.m. Ingen af de tre uddannelser er som udgangspunkt rettet specielt mod indvandrere, men de anvendes i stigende grad af indvandrere og efterkommere, hvilket på AVU og HF-enkeltfag har betydet at der er udviklet tiltag i tilknytning til uddannelserne som er rettet specifikt mod tosprogede, og i forhold til FVU, at uddannelsens oprindelige fokus og mål forskydes på grund af en anden målgruppe end den tiltænkte.

AVU blev oprettet i 1989 som en almendannende voksenuddannelse der blandt andet havde som målsætning at udvikle kompetencer der var relevante for arbejdsmarkedet. I 2008 gennemførte man en reform af AVU-området, hvilket blandt andet betød at målsætningen ikke længere nævner arbejdsmarkedet, men har et betydeligt øget fokus på at kvalificere til videre uddannelse (Undervisningsministeriet 2006b, § 1, Undervisningsministeriet 2008, $\S 1)$. Dermed går udviklingen inden for AVU-området i en vis grad i den modsatte retning af målsætningerne på integrationsområdet, som i stigende

\footnotetext{
${ }^{22}$ Det drejer sig for eksempel om kursusforløbet Hava Familie og Integration, gennemført af FOF Århus, der havde til formål - blandt andet gennem en række kulturarrangementer - ,at skabe personlige og faglige netværk til og mellem yngre etniske kvinder“ (Integrationsministeriet 2009h).

${ }^{23}$ Et eksempel herpå er etableringen af FVU-forløb i Rosenhøj, Århus i samarbejde mellem Frit Oplysningsforbund Århus, en lokal boligforening, en lokal skole og Århus Amt (www.dfs.dk).
} 
grad fokuserer på at sikre indvandrere kompetencer til hurtigst muligt at komme i arbejde og blive selvforsørgende ${ }^{2425}$.

De afsluttende prøver på AVU giver samme ret til fortsat uddannelse som folkeskolens prøver efter 9. og 10. klasse. Som det fremgår af nedenstående figur 3.2.1 og tabel 3.2.1, har det samlede antal kursister på AVU været faldende de sidste ti år, mens andelen af indvandrere har været jævnt stigende fra 10,51 pct. i 1996 til 22,36 pct. i $2007^{26}$.

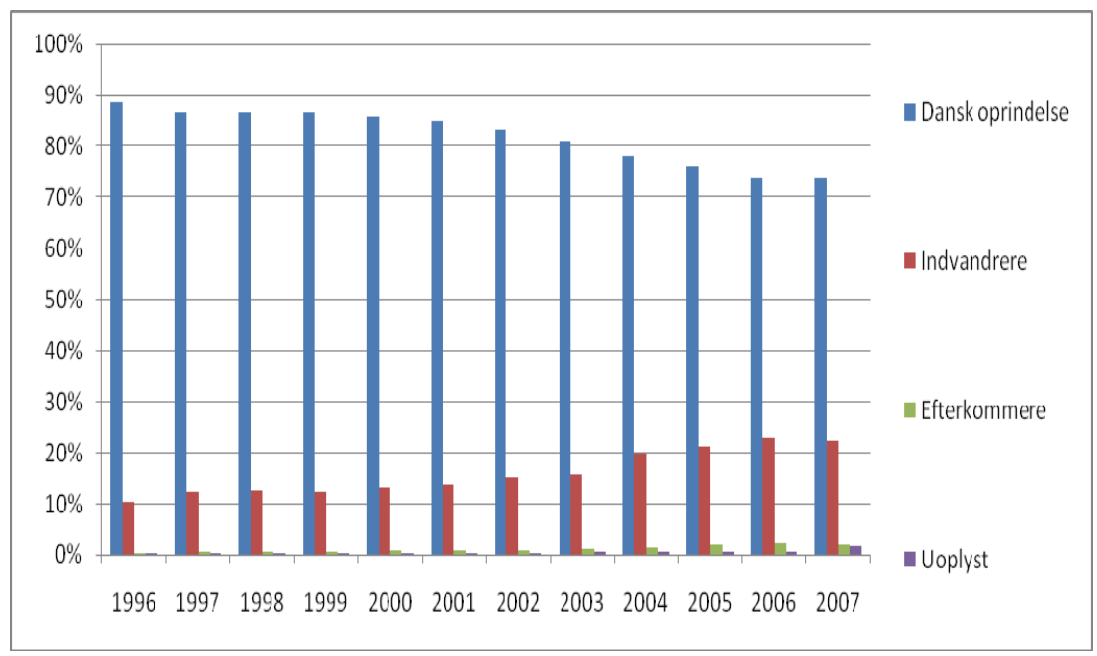

Figur 3.2.1 Andel kursister på AVU, fordelt efter oprindelse

Kilde: Danmarks Statistik

Den stigende andel indvandrere skyldes først og fremmest, og særligt siden årtusindeskiftet, et fald i det samlede antal kursister på AVU; samtidig med det har antallet af indvandrere og efterkommere været nogenlunde stabilt, og det er faldet mindre end antallet af kursister med dansk oprindelse. Det er meget forskelligt i de forskellige dele af landet, hvor stor en andel indvandrere udgør, det strækker sig fra 50 pct. på Københavns VUC til 2 pct. på VUC Thy-Mors (EVA 2005a, p. 45) ${ }^{27}$.

\footnotetext{
${ }^{24}$ Se i øvrigt kapitel 2 vedrørende udviklingen i de nationale strategier.

${ }^{25}$ Udviklingen skal ses i sammenhæng med regeringens målsætning om at 95 pct. af en årgang skal gennemføre en ungdomsuddannelse.

${ }^{26}$ Også andelen af efterkommere har været stigende fra 0,44 pct. i 1996 til 2,17 pct. i 2007, men udgør fortsat en meget lille del af de samlede antal kursister.

${ }^{27}$ VUC Thy-Mors der ligger i et tyndt befolket landområde mener dog at andelen af tosprogede er højere og ligger på 10-15 pct.
} 
Tabel 3.2.1 Antal kursister på AVU, fordelt efter oprindelse

\begin{tabular}{lrrrrrr}
\hline AVU & $\mathbf{1 9 9 7}$ & $\mathbf{1 9 9 9}$ & $\mathbf{2 0 0 1}$ & $\mathbf{2 0 0 3}$ & $\mathbf{2 0 0 5}$ & $\mathbf{2 0 0 7}$ \\
\hline Dansk oprindelse & 116.609 & 124.798 & 91.509 & 72.608 & 69.653 & 35.812 \\
Indvandrere & 16.757 & 17.884 & 14.746 & 15.801 & 19.513 & 10.852 \\
Efterkommere & 726 & 956 & 923 & 1.063 & 1.818 & 1.051 \\
Uoplyst & 589 & 468 & 362 & 459 & 475 & 825 \\
\hline
\end{tabular}

Kilde: Danmarks Statistik

Allerede i 1980'erne blev AVU anvendt relativt meget af indvandrere, hvilket førte til at man i slutningen af 1980'erne oprettede faget Dansk som fremmedsprog, det der i dag hedder Dansk som andetsprog, og som i dag udbydes på basisniveau og på niveauerne $\mathrm{G}$ til $\mathrm{D}$, hvor $\mathrm{G}$ svarer til 9. klasse, E til 10. klasse og D giver sammenhæng til HF-uddannelsen ${ }^{28}$. Det vejledende timetal har, siden faget blev indført, været det dobbelte af timetallet for faget dansk, mens ramme og indhold for den mundtlige prøve har været den samme for de to fag. Med AVU-reformen, som trådte i kraft 1. august 2009, går Dansk som andetsprog fra at være et tilbudsfag til at være et kernefag som uddannelsesinstitutionen skal udbyde. Dermed går faget altså fra at være et tilbudsfag med 180 timer der udbydes på ét niveau, til at få status som kernefag med i alt 465 timer som udbydes på fem niveauer ${ }^{29}$. Med den nye lov ækvivalerer de to dansk-fag hinanden, men adskiller sig fra hinanden i både indhold, prøver og vurderingskriterier. Tanken er at undervisningen i Dansk som andetsprog skal udnytte indvandrernes flersproglige kompetencer, hvilket der bliver taget positivt i mod, idet det betragtes som „nogle af de positive ryk i retning af et nyt og mere inkluderende syn på flersproglighed i det danske uddannelsessystem“ (Svensson 2009, p. 23).

Danmarks Evalueringsinstitut (EVA) foretog i 2005 en evaluering af VUC, herunder AVU. En af de anbefalinger de i den forbindelse kom med, var at lærerne skal efteruddannes således at de „rustes bedre til at løfte opgaven med et stigende antal svage, uddannelsesfremmede unge og med de tosprogede“ (EVA 2005a, p. 7). Med AVU-reformen har man fulgt anbefalingen og indført større krav til dansklærernes kompetencer, idet det er et krav at lærerne i dansk som andetsprog skal have „gennemført uddannelsen til underviser i dansk som andetsprog for unge og voksne eller have tilsvarende kvalifikationer“ (Undervisningsministeriet 2008, § 26 stk. 2). Også for

\footnotetext{
${ }^{28}$ Ifølge BEK 292, 1. april 2009, som træder i kraft 1. august 2009.

${ }^{29}$ Til sammenligning har faget dansk i alt 360 timer for de fem niveauer (Undervisningsministeriet 2009a, bilag 2)
} 
de øvrige faglærere på AVU signalerer reformen et øget fokus på målgruppen af tosprogede kursister, idet vejledningerne i alle fag vil have fokus på hvordan undervisningen kan tilrettelægges så den matcher tosprogede kursisters behov og ressourcer (Svensson 2009).

Ifølge EVA’s evaluering er tosprogede på VUC generelt præget af en svag faglig baggrund, og de har i mange tilfælde „svært ved at forholde sig til undervisningskulturen på VUC med projektarbejde og medindflydelse på arbejdsformerne“ (EVA 2005a, p. 47), men de betragter det samtidig „som både overraskende og meget positivt at lærerne ikke blot accepterer spørgsmål i undervisningen, men ofte direkte opfordrer kursisterne til at spørge“ (Svensson 2008, p. 24).

Det er VUC'ernes egen vurdering at både deres miljø og undervisningstilbud er meget velegnede til at styrke integrationen. En vurdering der støttes af en stor del af de tosprogede selv, idet de fremhæver at de på VUC kan lære sammen med dansksprogede kursister, i modsætning til sprogskolen hvor de ofte har følt sig isoleret fra de dansksprogede (Svensson 2008). En del har dog vanskeligt ved at følge med, og EVA konkluderede i 2005 (EVA 2005a) at det er et generelt problem at der mangler en mulighed for at skabe en god overgang mellem sprogcenter og VUC. Det har VUC'erne flere steder forsøgt at udvikle tilbud der kan rette op på ${ }^{3031}$. Fra august 2005 blev det muligt at oprette Dansk som andetsprog basis som forsøgsfag, hvormed man forsøgte at „lukke hullet“ mellem sprogskole og AVU (EVA 2005a, p. 51).

Indvandrere og efterkommere på AVU følger generelt flere fag og aflægger prøve i flere fag end danske kursister (33 pct. tosprogede har tre til fire fag; det gælder kun 17 pct. af danskerne). Ifølge EVA’s evaluering er de relativt målrettede og går i høj grad på AVU med henblik på at forbedre deres arbejdsmarkedskvalifikationer, arbejdssituation og for at kvalificere sig til videre uddannelse. Således angiver 61 pct. af indvandrerne på AVU at de ønsker at fortsætte på uddannelse. Det samme gælder kun for 29 pct. af danskerne (EVA 2005a, pp. 47f). Der er da også en større andel af de tosprogede end de dansksprogede der har besluttet sig for at fortsætte på HFenkeltfag efter AVU (41 pct. mod 22 pct.) (DMA 2005, p. 42).

\footnotetext{
${ }^{30}$ Det gælder blandt andet VUC Fyn, der har indgået samarbejde med Dansk Flygtningehjælp om et projekt for tosprogede der har færdiggjort sprogskolen, men ikke har forudsætninger til at følge de eksisterende tilbud på VUC, VUC Storstrøm, som sammen med sprogskolen har udviklet faget Omverdensforståelse, og VUC Fredericia, som har udviklet en særlig pakkeløsning til tosprogede som kombinerer kulturfag og formidling med kernefag (EVA 2005a)

${ }^{31}$ Problemstillingen har især konsekvenser på FVU; den vil blive berørt nærmere nedenfor.
} 
I en undersøgelse af hvorvidt AVU-kursister videreuddanner sig, konkluderer Lars Klewe (2008) at for kursister med grundskolen som højeste fuldførte uddannelse, har lige så mange kursister med indvandrerbaggrund som kursister med dansk baggrund videreuddannet sig 10 år efter at de fulgte et AVU-kursus. For kursister fra årgang 2002 gælder at lidt flere kursister med indvandrerbaggrund end kursister med dansk baggrund var under uddannelse i 2005. Da indvandrere og efterkommere generelt har en lavere uddannelsesfrekvens end danskere, er der noget der tyder på at der ligger et uddannelsespotentiale gennem deltagelse i AVU, især for de yngre kursister (Klewe 2008).

Samtidig tyder undersøgelsens resultater på at AVU i sig selv ikke er tilstrækkeligt til at sikre beskæftigelse, men at indvandrere der anvender AVU som springbræt til videre uddannelse, lader til at få god adgang til arbejdsmarkedet (Klewe 2008).

FVU blev oprettet med start i 2001 som led i regeringens målsætning om at alle voksne skulle have ret og adgang til at lære hele livet. I et forsøg på at sikre adgang for alle, blev der lagt vægt på rummelighed, og FVU er karakteriseret ved stor fleksibilitet i form af mange forskellige udbydere, niveauer, timetal, m.m. (Borberg 2000; EVA 2005b). FVU er målrettet voksne der har behov for at forbedre basale færdigheder i læsning/skrivning og regning. Der er to retninger: FVU-læsning og FVU-matematik. Niveauet går færdighedsmæssigt til det der svarer til 9. klasse. FVU er primært udviklet med henblik på kursister med dansk som modersmål. Indtil FVU-loven blev ændret i 2007, kunne trin 1 i læsning tilrettelægges særligt for deltagere med dansk som andetsprog (Undervisningsministeriet 2005). Målgruppen var indvandrere med velfungerende dansk talesprog, men med behov for at forbedre/supplere læsning, stavning og skriftlig fremstilling. De reelle kursister var dog i stort omfang indvandrere som havde brug for at forbedre og supplere grundlæggende færdigheder både skriftligt og mundtligt (Due 2005). Med lovændringen i 2007 bortfaldt muligheden for særlig tilrettelæggelse af trin 1. Ændringen blev indført for at tydeliggøre at målgruppen er ,personer, der taler dansk“, og dermed også tydeliggøre FVU-tilbuddets profil (Erhvervsog Selskabsstyrelsen 2006). Samtidig blev sprogcentrenes udbudsret dog udvidet således at de efter overenskomst med voksenuddannelsescenteret (VUC) kan udbyde alle FVU-fag (Undervisningsministeriet 2007a).

Der er endnu ikke opgørelser, der viser om lovændringen har haft betydning for andelen af indvandrere på FVU. 
Tabel 3.2.2 Antal kursister på FVU, fordelt efter oprindelse

\begin{tabular}{lrrrrrr}
\hline FVU & $\mathbf{2 0 0 2}$ & $\mathbf{2 0 0 3}$ & $\mathbf{2 0 0 4}$ & $\mathbf{2 0 0 5}$ & $\mathbf{2 0 0 6}$ & $\mathbf{2 0 0 7}$ \\
\hline I alt & 6.882 & 18.227 & 21.253 & 23.126 & 27.302 & 15.390 \\
Dansk oprindelse & 4.451 & 11.624 & 13.407 & 13.994 & 15.011 & 6.644 \\
Indvandrere & 2.300 & 6.293 & 7.417 & 8.583 & 11.276 & 7.796 \\
Efterkommere & 71 & 177 & 255 & 370 & 421 & 274 \\
Uoplyst & 60 & 133 & 174 & 179 & 594 & 676 \\
\hline
\end{tabular}

Kilde: Danmarks Statistik

Som det fremgår af tabel 3.2.2, steg det samlede antal kursister jævnt fra 2002 til 2007. Antallet af indvandrere og efterkommere steg endnu mere, således at indvandrere, jf. figur 3.2.2, i 2002 udgjorde en tredjedel (33,42 pct.) af kursisterne, et tal der i 2007 var steget til 50,66 pct. Udviklingen er sket til trods for at FVU ikke er tænkt som et tilbud specifikt til indvandrere, men tværtimod primært til danskere med læse-, stave- og regneproblemer. Det er særligt på de lavere trin der går mange indvandrere (i 2004 var 44 pct. af kursisterne på læsning trin 1 indvandrere mod 23 pct. på trin 4). Udviklingen skal ses i lyset dansk krav til indfødsret, klippekort på sprogcentre og mangel på alternativer. Flere undersøgelser tyder på at indvandrere på FVUlæsning snarere anvender FVU som sprogundervisning end som den læseundervisning den er tænkt som (EVA 2005b, Lysholm m.fl. 2004, Carter m.fl. 2004, Due 2006). Det fremgår således blandt andet af Carters undersøgelse at en betydelig del af indvandrerne på FVU-læsning har en videregående eller gymnasial uddannelse før de starter på FVU-læsning, mens danskerne enten har grundskolen (75 pct.) eller en erhvervsfaglig uddannelse (25 pct.) som højeste uddannelse før FVU-læsning (Carter m.fl. 2004, p. 12). Ifølge Lysholm m.fl. (2004) anvendes FVU nogle steder som „erstatning“ for AVU's Dansk som andetsprog, dels fordi indvandrerne på FVU følger hold sammen med danskere, dels fordi det er lettere at oprette hold på FVU end på AVU, idet kravene til holdstørrelser er betydeligt mindre på FVU end på AVU. I forbindelse med AVU-reformen i 2009 tilbydes Dansk som andetsprog nu som basis, som supplement til dansk-tilbuddet til indvandrere. 


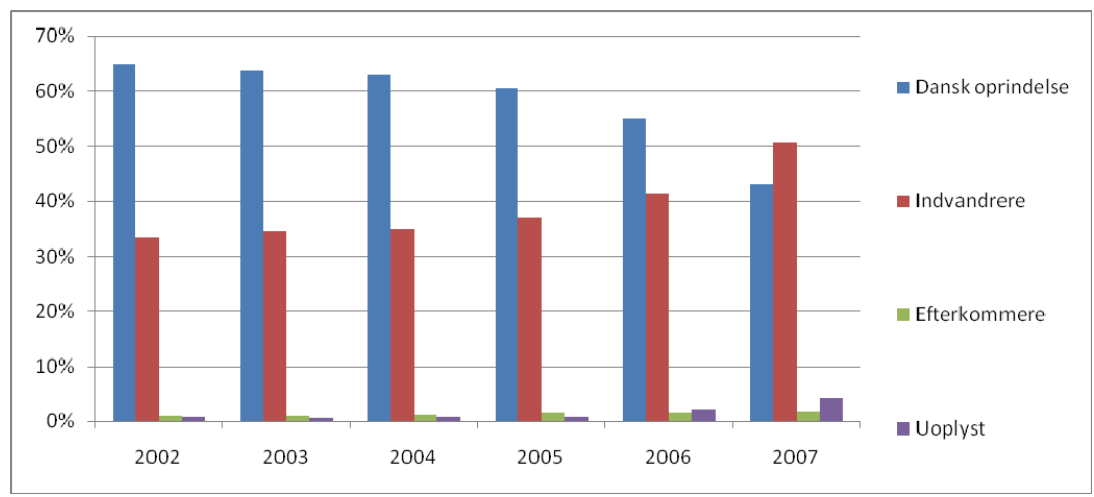

Figur 3.2.2 Andel kursister på FVU, fordelt efter oprindelse Kilde: Danmarks Statistik

Særligt i forbindelse med FVU-læsning, men også i forbindelse med FVUmatematik, er det ifølge Carters undersøgelse et problem at mange af indvandrerne, herunder de højtuddannede, har problemer med læseforståelsen. Det kommer især til udtryk i forbindelse med prøverne, og der er da også færre indvandrere end danskere der gennemfører både de sidste trin af læsning og matematik med prøve. Det tilskrives til dels at mange af indvandrernes reelle behov som nævnt ikke er læsning, men sprogundervisning (Carter m.fl. 2004, p. 76).

Endelig har FVU indgået i forløb der kombinerer undervisning, praktik, vejledning og jobsøgning ${ }^{32}$. Projekterne er bygget op med fokus på samarbejde mellem relevante aktører, en form der beskrives nedenfor i forbindelse med særlige initiativer rettet mod beskæftigelse.

HF-enkeltfag er undervisning på gymnasialt niveau, rettet mod ,voksne med interesse for viden, fordybelse, perspektivering og abstraktion“. Uddannelsen har til formål ,at voksne kursister opnår almendannelse, viden og kompetencer, som danner grundlag for videre uddannelse eller øger mulighederne på arbejdsmarkedet“; uddannelsen skal derudover sikre at kursisterne opnår forudsætninger for aktiv medvirken i et demokratisk samfund (Undervisningsministeriet 2007b).

\footnotetext{
${ }^{32}$ Det drejer sig for eksempel om projekterne Netværkslokomotivet i Vejle (Netværkslokomotivet 2009) og „Dansk på vej til arbejde“ i Nordsjælland (Bie m.fl. 2005).
} 


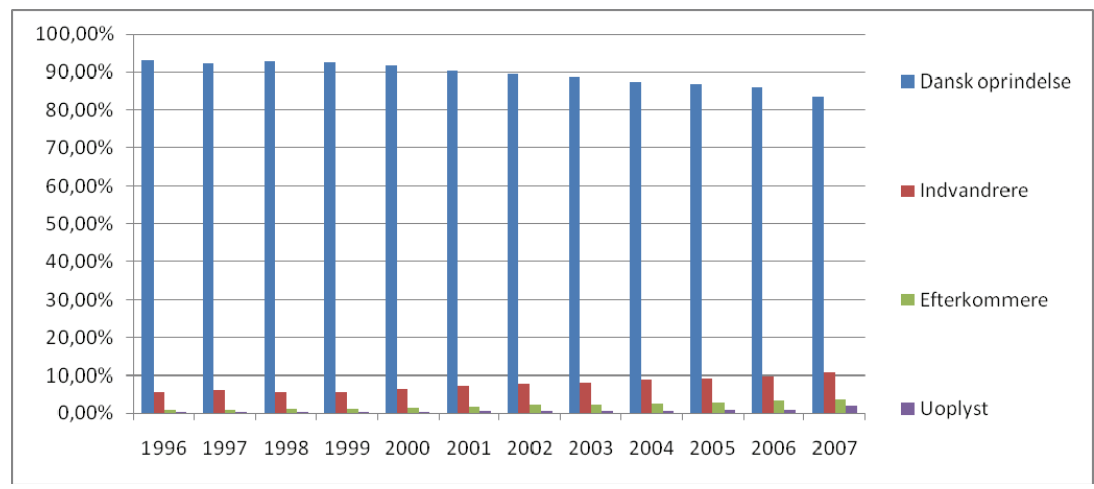

Figur 3.2.3 Andel kursister på HF-enkeltfag, fordelt efter oprindelse Kilde: Danmarks Statistik

Indvandrere udgør en jævnt stigende andel af kursisterne på hf-enkeltfag, og de er jf. figur 3.2.3 gået fra at udgøre knapt 5,57 pct. i 1996 til godt en tiendedel med 10,56 pct. i 2007.

Tabel 3.2.3 Antal kursister på HF-enkeltfag, fordelt efter oprindelse

\begin{tabular}{lrrrrrr}
\hline HF enkeltfag & $\mathbf{1 9 9 7}$ & $\mathbf{1 9 9 9}$ & $\mathbf{2 0 0 1}$ & $\mathbf{2 0 0 3}$ & $\mathbf{2 0 0 5}$ & $\mathbf{2 0 0 7}$ \\
\hline I alt & 94.819 & 88.874 & 83.983 & 83.805 & 86.261 & 79.427 \\
Dansk oprindelse & 87.560 & 82.241 & 75.733 & 74.353 & 75.018 & 66.472 \\
Indvandrere & 5.865 & 5.117 & 6.175 & 6.938 & 7.974 & 8.419 \\
Efterkommere & 974 & 1.100 & 1.575 & 1.964 & 2.544 & 2.931 \\
Uoplyst & 420 & 416 & 500 & 550 & 725 & 1.605 \\
\hline
\end{tabular}

Kilde: Danmarks Statistik

I 1986 etablerede man en et-årigt fagpakke på HF, Gymnasialt indslusningskursus for flygtninge og indvandrere (GIF) ${ }^{33}$. Formålet med forløbet er at give indvandrere med en ikke-adgangsgivende gymnasial uddannelse fra hjemlandet mulighed for at supplere uddannelse således at den sidestilles med en dansk gymnasial adgangsgivende uddannelse (Undervisningsministeriet 2007c).

Optagelse på GIF kræver mindst 12 års skolegang, opholdstilladelse, dokumenteret beherskelse af dansk (i form af bestået AVU trin II, Studieprøven eller Dansk som andetsprog på SVU med mindst 7 på 7-trinskalaen) samt mindst fire års formel undervisning i engelsk således at det beherskes svarende til Folkeskolens Afgangsprøve. GIF udbydes i en humanistisk og

\footnotetext{
${ }^{33}$ GIF er ikke reguleret i HF-bekendtgørelsen, men i bekendtgørelsen for Gymnasial Supplering.
} 
en matematisk fagpakke. Institutioner der må udbyde almene gymnasiale uddannelser og HF, kan også udbyde GIF, der dog kun udbydes tre steder i landet.

Tabel 3.2.4 Antal kursister på GIF, fordelt efter oprindelse

\begin{tabular}{lrrrrrr}
\hline GIF & $\mathbf{1 9 9 7}$ & $\mathbf{1 9 9 9}$ & $\mathbf{2 0 0 1}$ & $\mathbf{2 0 0 3}$ & $\mathbf{2 0 0 5}$ & $\mathbf{2 0 0 7}$ \\
\hline I alt & 166 & 170 & 84 & 170 & 205 & 68 \\
Dansk oprindelse & 0 & 0 & 0 & 28 & 2 & 2 \\
Indvandrere & 166 & 168 & 80 & 142 & 199 & 64 \\
Efterkommere & 0 & 2 & 2 & 0 & 2 & 0 \\
Uoplyst & 0 & 0 & 2 & 0 & 2 & 2 \\
\hline
\end{tabular}

Kilde: Danmarks Statistik

Som det fremgår af tabel 3.2.4, er det ikke et entydigt billede af udviklingen i elevtallet de sidste ti år, men der har i hele perioden været meget få elever på GIF.

Undervisere på GIF skønner at elever fra GIF klarer sig „helt godt“ efterfølgende (Wissing, m.fl. 2009). Rektorkollegiet undersøgte i 2001 integrationen af fremmedsprogede studerende på de lange videregående uddannelser og skønner tilsvarende at mange af GIF-kursisterne klarer sig udmærket på de videregående uddannelser, og at de ikke har problemer med deres sprogkundskaber i dansk, men mangler træning i danske studieteknikker (Rektorkollegiet 2001, p. 22). Den vurdering understøttes af Lund og Bertelsen, som i deres undersøgelse fra 2008, konkluderer at GIF-kursisterne klarer sig bedre end indvandrere med en dansk adgangsgivende eksamen, men dårligere end studerende med Studieprøven som adgangsgivende eksamen. Det vurderes også her at der er behov for at indvandrerne bliver bedre forberedt studieteknisk, kulturelt, socialt og (fag)sprogligt, og Jakob Lange anbefaler sammen med rapportens forfattere at det bliver muligt at tage et ekstra forberedelsesår på GIF (Lund m.fl. 2008, p. 211).

Erfaringer fra København og Århus har vist at tosprogede kursister på hfenkeltfag klarer sig dårligt på danskholdene, noget dansklærerne hverken har tid eller kompetencer til at afhjælpe. Man har forsøgt at etablere sprogværksteder og ekstraundervisning, men „det er lappeløsninger, som ikke hjælper“ (Wissing 2009). På den baggrund og på baggrund af de ret gode erfaringer der er med GIF, trods et snævert kursistgrundlag, søgte man Undervisningsministeriet om at oprette „GIF-dansk“ som enkeltfag. Ministeriet gav afslag, men har i stedet godkendt et forsøg med etablering af Dansk A som 
andetsprog på hf-enkeltfag. Forsøget startede to steder i 2008 og yderligere to steder i 2009 og kører frem til 2012. Dansk A som andetsprog adskiller sig fra Dansk A ved at være defineret som sprogfag som ækvivalerer Dansk A (Wissing 2009).

Etableringen af Dansk A som andetsprog skal ses i lyset af det stigende antal indvandrere og efterkommere på HF-enkeltfag.

\subsubsection{Erhvervsrettede voksenuddannelser}

Ud over de almene og forberedende uddannelser der er beskrevet ovenfor, er der en række erhvervsrettede voksen- og efteruddannelser. Kun arbejdsmarkedsuddannelserne (AMU), der har etableret flere tilbud som er specifikt målrettet indvandrere, vil blive gennemgået, mens de øvrige erhvervsrettede uddannelser (grundlæggende voksenuddannelse (GVU) og videregående voksenuddannelse (VVU)) ikke har iværksat særlige tiltag for indvandrere og heller ikke benyttes i stort omfang af indvandrere.

Både GVU og VVU blev oprettet i forbindelse med en ny erhvervsuddannelseslov der blev vedtaget i 2000, og som havde til formål at lave et mere samlet og fleksibelt videreuddannelsessystem for voksne med henblik på at bidrage til et uddannelsesmæssigt løft for de kortuddannede (Undervisningsministeriet 2000b, EVA 2005a). Der er tale om tilbud der er oprettet for at give mulighed for at tage henholdsvis en erhvervsuddannelse (på GVU) og det der svarer til en kort videregående uddannelse (på VVU) ved at kombinere erhvervserfaring med kompetencegivende uddannelse. Hverken GVU eller VVU anvendes meget af indvandrere, og EVA konkluderede i en evaluering fra 2007 at ,„øgningen til GVU er meget lille og ikke i fremgang“ (EVA 2007, p. 9). Uddannelsen kan, i kraft af dens anerkendelse af erhvervserfaring og brug af realkompetencevurdering, være en vej for indvandrere med erhvervserfaring til at få dansk uddannelsesbevis, men der er ikke tal der viser i hvilket omfang uddannelsen benyttes af indvandrere.

$A M U$ er målrettet faglærte og ufaglærte og består af korterevarende kursusforløb inden for i alt 12 fagområder ${ }^{34} .12$ efteruddannelsesudvalg er ansvarlige for udviklingen af kurserne. AMU er møntet på opkvalificering og

\footnotetext{
${ }^{34}$ Det drejer sig om Bygge/anlæg og industri, Handel, administration, kommunikation og ledelse, Industriens arbejdsmarkedsuddannelser, Køkken, restaurant, bager, konditor og kødbranchen, Mejeri og jordbrug, Metalindustrien, Pædagogisk område og social- og sundhedsområdet, Serviceerhvervene, Svejsning og fyringsteknik, Tekniske installationer og energi, Træets uddannelser og Transporterhvervene.
} 
kan derudover give merit til grundlæggende erhvervsrettede uddannelser. AMU-systemet er kendetegnet ved at bestå af mange kortere kurser som kan sammensættes efter virksomheders og deltageres aktuelle behov. Uddannelserne og kurserne udbydes primært på erhvervsskoler.

Der er udviklet flere konkrete kurser målrettet indvandrere, herunder arbejdsmarked, it og jobsøgning, introduktion til et brancheområde, introduktion til det danske arbejdsmarked, og praktik (Undervisningsministeriet 2009c).

Lærere i dansk som andetsprog skal have uddannelsen til underviser i dansk som andetsprog for voksne eller tilsvarende kvalifikationer. Der er dog behov for opkvalificering af AMU-lærere der underviser indvandrere i andre fag end dansk som andetsprog. Der er derfor netop udviklet et efteruddannelseskursus som udbydes første gang i efteråret 2009. Det er derudover besluttet at den nuværende pædagogiske grunduddannelse for lærere på AMU og på erhvervsuddannelserne skal afløses af en pædagogisk diplomuddannelse. I den forbindelse er der planer om at lade ,viden om at undervise tosprogede og viden om den kulturelle dimension i undervisning af tosprogede“ indgå som en del af uddannelsen (Undervisningsministeriet 2009b).

Vejledningen til AMU-loven fra 2004 angiver at AMU i forhold til indvandrere har til formål „at styrke deres mulighed for at fastholde eller få job og eventuelt deltage i yderligere uddannelse“ (Undervisningsministeriet 2004a). Som det fremgår af figur 3.2.4 og tabel 3.2.5 nedenfor, anvendes både de ordinære og de særligt tilrettelagte AMU-forløb i stigende grad af indvandrere og efterkommere. De to grupper udgjorde dog i 2007 med 6,83 pct. stadig ikke nogen stor andel af det samlede deltagerantal. 


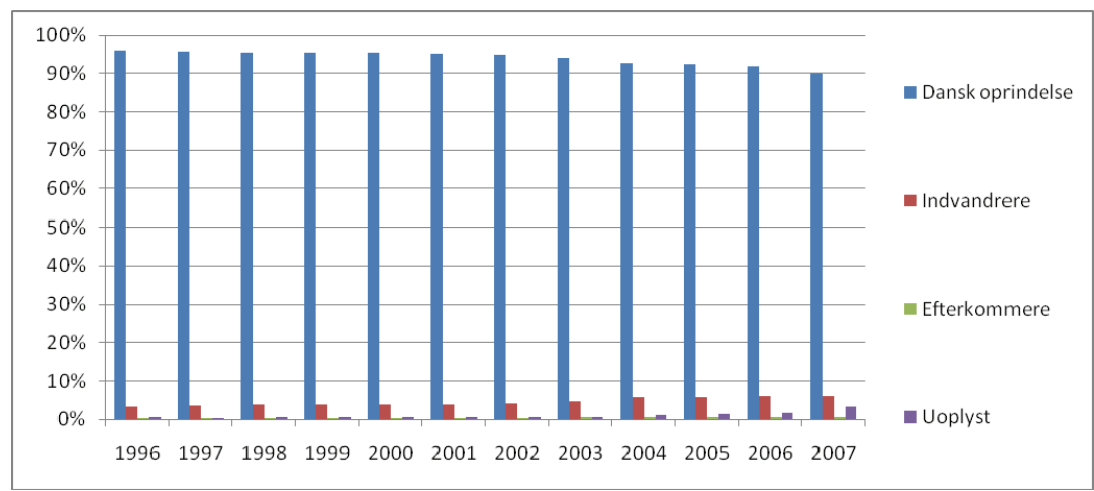

Figur 3.2.4 Andel kursister på AMU, fordelt efter oprindelse Kilde: Danmarks Statistik

Tabel 3.2.5 Antal kursister på AMU, fordelt efter oprindelse

\begin{tabular}{lrrrrrr}
\hline AMU & $\mathbf{1 9 9 7}$ & $\mathbf{1 9 9 9}$ & $\mathbf{2 0 0 1}$ & $\mathbf{2 0 0 3}$ & $\mathbf{2 0 0 5}$ & $\mathbf{2 0 0 7}$ \\
\hline I alt & 581.211 & 810.954 & 468.619 & 429.086 & 743.550 & 723.296 \\
Dansk oprindelse & 555.863 & 773.603 & 446.154 & 403.915 & 686.884 & 650.320 \\
Indvandrere & 21.068 & 30.667 & 18.048 & 20.475 & 42.982 & 44.514 \\
Efterkommere & 1.708 & 2.677 & 1.923 & 1.959 & 4.028 & 4.890 \\
Uoplyst & 2.572 & 4.007 & 2.494 & 2.737 & 9.656 & 23.572 \\
\hline
\end{tabular}

Kilde: Danmarks Statistik

Langt størstedelen (omkring 95 pct.) af de indvandrere der i 2005 deltog i AMU, deltog på ordinære uddannelser, mens kun 5 pct. benyttede AMU's særlige tilbud til flygtninge og indvandrere. En arbejdsgruppe under Undervisningsministeriet undersøgte hvorfor de særlige forløb ikke blev anvendt i større omfang, og pegede blandt andet på „økonomiske forhold, begunstigelse af dansk som andetsprog (...), lokale problemer med at få samarbejdet mellem forskellige aktører op at stå, og at ledige flygtninge og indvandrere er en målgruppe, der bliver stadigt svagere i forhold til faglige og sproglige forudsætninger“ (Undervisningsministeriet 2007d, p. 1f).

Gruppen uoplyst stiger kraftigt i de sidste år, der er ifølge Undervisningsministeriet (2009b) kraftige indikationer på, at der er tale om nyindvandret arbejdskraft. Hvis den gruppe tælles med, er mere end 10 pct. af deltagerne i AMU af udenlandsk herkomst, hvilket svarer meget godt til befolkningsandelen. Der er dog relativt få, der benytter de særlige tilbud for indvandrere. 
I marts 2007 ønskede Rådet for erhvervsrettet efter- og videreuddannelse $\left(\mathrm{REVE}^{35}\right)$ via Handlingsplan for kvalificering af flygtninge og indvandrere via AMU-programmet (Undervisningsministeriet 2007d) at sætte fokus på hvordan AMUs indsats over for indvandrere kunne styrkes, ikke mindst indsatsen over for ledige. Handlingsplanen pegede blandt andet på udviklingen af ,jobpakker“ og forstærket brug af en såkaldt trappemodel med henblik på at kvalificere flere indvandrere i arbejde via AMU.

Ifølge Undervisningsministeriet (2009b) steg antallet af indvandrere og efterkommere der benytter AMU yderligere i 2007-2009. Andelen der benytter de særlige tilbud for flygtninge og indvandrere er fortsat lille, men dog i vækst. Imidlertid er det stadig først og fremmest de beskæftigede, der benytter AMU.

Der blev udviklet 12 jobpakker, bygget op om AMU's faglige kurser, inden for områder med gode beskæftigelsesmuligheder (Undervisningsministeriet 2007d). Det centrale i jobpakkerne er at der er tale om et sammenhængende aktiveringsforløb hvor flere aktiveringsredskaber spiller sammen. I trappemodellen bevæger man sig trin for trin fra uddannelse og praktik til ordinær beskæftigelse ${ }^{36}$. De evalueringer der er foretaget af jobpakkernes effekt, er modsatrettede. Rambøll vurderer i sin evaluering fra 2008 at jobpakkerne ,ikke resulterer i anderledes forløb for de ledige, end det jobcentrene ellers ville have gjort“ (Rambøll 2008a, p. 2). De anfører dog at jobpakkerne for de svageste grupper kan have en bedre beskæftigelseseffekt end enkeltstående aktivering. I modsætning hertil konkluderer konsulentvirksomheden mhtconsult i sin slutevaluering fra 2009 af VIP2 ${ }^{37}$ at jobpakkerne har „været i høj kurs i alle metodekommuner“ (mhtconsult 2009, p. 7). Evalueringen nævner dels at kommunerne har udviklet flere end de oprindelige 12 jobpakker og fokuserer på samarbejdet mellem parterne som helt centralt for konceptet og succesen (mhtconsult 2009).

Der er to typer af tilbud inden for AMU som er rettet særligt mod flygtninge og indvandrere:

\footnotetext{
${ }^{35}$ REVE hedder siden 2009 VEU-rådet.

${ }^{36}$ Trappemodellen blev introduceret med firepartsaftalen i 2002. Med firepartsaftalen fra 2006 blev der opfordret til øget brug af trappemodellen og ,jobpakker“ blev introduceret (Undervisningsministeriet 2007d).

${ }^{37}$ Virksomhedsrettet Integration Projekt 2 er et projekt mellem DA, LO og KL indgået i forbindelse med firepartsaftalen fra 2006. Projektet har til formål at udvikle metoder og dele viden og fokuserer primært på anvendelse og udvikling af jobpakker.
} 
- Arbejdsmarkedsuddannelser (kurser) udviklet til flygtninge og indvandrere, for eksempel dansk som andetsprog eller introduktion til branche eller konkrete jobfunktioner

- Særlige forløb for flygtninge og indvandrere hvor en eller flere arbejdsmarkedsuddannelser kan kombineres med undervisning i dansk som andetsprog. Der kan derudover indgå praktik i forløbene.

Dansk som andetsprog tilbydes på de tre niveauer basis, alment og udvidet og er rettet mod personer der har dansksproglige forudsætninger der ligger mellem bestået Prøve i Dansk 1 og bestået Prøve i Dansk $2^{38}$. Undervisningen i dansk som andetsprog på AMU adskiller sig fra anden sprogundervisning ved at tage udgangspunkt i et værksted og/eller et konkret fagområde. Det betyder at man i danskundervisningen først og fremmest arbejder med det sprog deltagerne har brug for i forhold til den faglige undervisning (Undervisningsministeriet 2006a). „Erfaringerne med disse uddannelser er, at man ved at kombinere undervisning $i$ et specifikt fag med undervisning $i$ dansk som andetsprog kan opnå en udviklingsproces hos deltagerne, som både udvikler deres faglige og deres dansksproglige kompetencer, og dermed fremmer deres muligheder for at begå sig på det danske arbejdsmarked og i samfundet generelt“ (Undervisningsministeriet 2006a, p. 31). Erfaringerne bekræftes af Bertelsen m.fl. (2006) og af Hjermov m.fl. (2007), der konkluderer at kombinationen af undervisning i sprog og et specifikt fag udvikler både det sproglige og det faglige niveau og fører til en positiv spiral hvor de sproglige og de faglige kompetencer gensidigt forstærker hinanden. Både lærere og kursister giver da også udtryk for at både sprogundervisningen og den fagrelaterede undervisning fungerer bedst når fagene integreres (Bertelsen m.fl. 2006, Hjermov m.fl. 2007).

Fra 2007 blev arbejdsmarkedsuddannelsen fagunderstøttende dansk som andetsprog etableret. Der er tale om et kort fleksibelt kursus af en varighed på højest ti dage som kun kan udbydes sammen en eller flere andre arbejdsmarkedsuddannelser som en del af et særligt forløb for flygtninge og indvandrere. Indholdet i uddannelsen bestemmes af de sprogbehov der opstår i den konkrete faglige kontekst (Ramsøe 2007b).

Som det fremgår af nedenstående tabel 3.2.6, har der været en markant stigning i aktiviteten på AMU-kurser særligt tilrettelagt for flygtninge og indvandrere fra 2004 til 2008, bortset fra et mindre fald i 2006.

\footnotetext{
${ }^{38}$ Prøverne refererer til Danskuddannelsesprøverne på sprogcentrene.
} 
Tabel 3.2.6 Antal kursister på de særlige kurser for flygtninge og indvandrere

\begin{tabular}{lrrrrr}
\hline & $\mathbf{2 0 0 4}$ & $\mathbf{2 0 0 5}$ & $\mathbf{2 0 0 6}$ & $\mathbf{2 0 0 7}$ & $\mathbf{2 0 0 8}$ \\
\hline Dansk herkomst & 34 & 67 & 90 & 20 & 110 \\
Udenlandsk herkomst & 767 & 905 & 650 & 1199 & 1644 \\
Uoplyst & 8 & 3 & 86 & 411 & 1835 \\
I alt & 809 & 975 & 826 & 1630 & 3589 \\
\hline
\end{tabular}

Kilde: Undervisningsministeriet 2009b.

Det kan altså tyde på at AMU kombineret med tilbuddet om Dansk som andetsprog begynder at blive mere attraktivt for indvandrere. Det var således i 2008 næsten tre fjerdedele (72,2 pct.) af kursisterne på kurser der var rettet mod indvandrere, som fulgte dansk som andetsprog (Undervisningsministeriet 2009b). Men AMU har ikke været anvendt i det omfang det har været ønsket fra politisk side. Som hindring peger erfaringer fra TUP-projektet ${ }^{39}$ „Opsøgende indsats overfor flygtninge og indvandrere“ på et meget mangelfuldt samarbejde mellem aktørerne. Særligt kommunerne lader ifølge rapporten ikke til at prioritere indsatsen over for ledige indvandrere højt (Undervisningsministeriet 2009b).

Det lader således til at mulighederne for at kombinere sproglig og faglig undervisning kan bidrage til at både sprog og fag læres bedre. Det tyder endvidere på at AMU kan være et godt tilbud for mange indvandrere, men også at en bedre udnyttelse af mulighederne kræver at relevante aktører, ikke mindst de kommunale jobcentre, samarbejder og prioriterer indsatsen. Der er en stadig vækst i gruppen af personer, som ikke har dansk herkomst, der benytter AMU. Størst vækst er der i gruppen med uoplyst herkomst. Der har samtidig været en positiv udvikling i anvendelsen af de særlige tilbud til flygtninge og indvandrere. Det er Undervisingsministeriets opfattelse at handlingsplanen for kvalificering af af flygtninge og indvandrere via AMUprogrammet har bidraget til at flere i målgruppen benytter AMU’s særlige tilbud til flygtninge og indvandrere.

\subsubsection{Det ordincere uddannelsessystem}

Ud over de uddannelsestilbud der organisatorisk er defineret som voksen- og efteruddannelsestilbud, er også en del af ungdomsuddannelserne relevante at gennemgå her. Dels fordi de har iværksat tiltag der er særligt rettet mod

\footnotetext{
${ }^{39}$ TUP-projekter er udviklingsprojekter finansieret af Undervisningsministeriets Tværgående UdviklingsPulje.
} 
voksne indvandrere, dels fordi de i relativt stort omfang anvendes af voksne indvandrere. Det drejer sig om nogle af erhvervsuddannelserne (EUD og VEUD $^{40}$ ), særligt inden for social- og sundhedsområdet, og om nogle af professionsbacheloruddannelserne, i sær lærer- og pædagoguddannelserne.

EUD er erhvervsuddannelser der typisk varer tre til fire år. Der er tre adgangsveje til EU's: skoleadgangsvejen, praktikadgangsvejen og Ny Mesterlære. Disse efterfølges af et hovedforløb som veksler mellem skole og praktik i en virksomhed. Der findes i alt 109 erhvervsuddannelser.

Erhvervsuddannelserne har været kendetegnet ved et meget stort frafald blandt eleverne, ikke mindst blandt indvandrere og efterkommere. I 2004 var frafaldet blandt unge udlændinge således oppe på omkring 60 pct. og dermed dobbelt så højt som frafaldet blandt etnisk danske elever (Frimodt m.fl. 2009, p.5). Der er på den baggrund igangsat en række initiativer med henblik på at fastholde unge indvandrere og efterkommere på erhvervsuddannelserne ${ }^{41}$. Da de primært er rettet mod unge, vil de ikke blive beskrevet nærmere her.

På enkelte erhvervsuddannelser er der dog relativt mange voksne indvandrere. Det gælder især social- og sundhedshjælperuddannelserne, hvor der er åbnet mulighed for at dispensere fra kravet om obligatorisk engelsk. På de øvrige erhvervsuddannelser er der mulighed for at „,de enkelte uddannelser kan tilrettelægges således, at eleverne på et eller flere tidspunkter inden udløbet af det almindelige uddannelsesforløb - kan afslutte forløbet med en uddannelse, der giver erhvervskompetence“ (Pedersen 2006a). Der er indført mulighed for trin- og niveaudeling, der giver mulighed for at tilpasse det faglige teoretiske niveau til elevernes forudsætninger, herunder at fravælge fag der er for vanskelige. Derved er det muligt for flere indvandrere at gennemføre en kompetencegivende erhvervsuddannelse. I 2004 blev loven om grundlæggende social- og sundhedsuddannelser ændret, således at det blev muligt at etablere særligt tilrettelagte „grundforløb for voksne med behov for undervisning i dansk sprog, kultur- og samfundsforståelse“ (Undervisningsministeriet 2004b, § 2, stk. 4).

Erhvervsuddannelsernes grundforløb er som udgangspunkt på 20 uger. Det kan udvides op til 60 uger, afhængigt af behov. Varianter af de udvidede

\footnotetext{
${ }^{40}$ VEUD, voksen-erhvervsuddannelser er erhvervsuddannelser rettet mod voksne over 25 år. De adskiller sig fra de ordinære erhvervsuddannelser i forhold til støttemuligheder, men ikke fagligt, hvorfor VEUD ikke vil blive gennemgået særskilt.

${ }^{41}$ Initiativerne skal ses i forbindelse med regeringens målsætning om at 85 pct. af en ungdomsårgang i 2010 skal have en ungdomsuddannelse; i 2015 er målet 95 pct., jf. regeringsgrundlaget „Nye mål“.
} 
grundforløb er blandt andet rettet mod tosprogede og inkluderer undervisning i erhvervsrettet andetsprogsdansk (EA). Siden 2006 har EA været et centralt beskrevet fag. Faget indgår som led „i den samlede indsats for at øge gennemførelsesraten blandt tosprogede elever i erhvervsuddannelserne“ (Norlyk 2009). Det skal ske ved at styrke og udvikle de tosprogede elevers kommunikative, sproglige og kulturelle kompetencer. Målet er først og fremmest at faget skal kunne understøtte undervisningen og uddannelsen af eleven både i skolen og i virksomheden således at eleven bliver i stand til at anvende sproget funktionelt i sammenhænge der vedrører udannelse, arbejde, erhvervsliv og samfund. I formål og mål for faget er der lagt vægt på samme elementer som i faget fremmedsprog i erhvervsuddannelserne (Norlyk 2009).

Flere social- og sundhedsskoler har deltaget i Equalprojekter med fokus på at få kvinder med anden etnisk baggrund end dansk ind på sosuuddannelserne. Blandt andet har social- og sundhedsskolen i København, CBSI Sprogcenter, FOA og Københavns kommune fra 2004-2007 samarbejdet omkring projektet „Fremme af uddannelse og beskæftigelse inden for social- og sundhedsområderne for kvinder med anden etnisk baggrund end

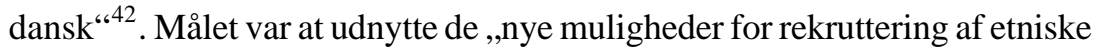
minoriteter uden de fornødne formelle kompetencer til social- og sundhedsskolerne“, hvilket blev muliggjort med ændringen af lov om grundlæggende social- og sundhedsuddannelser i 2004, hvor der blev åbnet mulighed for at etablere særlige grundforløb. Projektet var vellykket og resulterede ifølge mhtconsults evaluering (mhtconsult 2008) i et markant lavere frafald end på sosu-uddannelser generelt. Successen tilskrives blandt andet samarbejdet mellem relevante aktører. Som barriere peger evalueringen på at kvinderne har haft vanskeligt ved at kombinere uddannelsen med deres familieliv (mhtconsult 2008, p.5).

I januar 2008 blev „ny mesterlære“ introduceret med henblik på at flere unge - herunder ,praktisk orienterede unge og unge med udenlandsk baggrund“ - skulle have en uddannelse, samt på at mindske frafaldet på erhvervsuddannelserne (Regeringen 2005a). I regeringsgrundlaget fra 2005 blev det fremhævet at mesterlæren ville kunne medvirke til at opfylde målsætningen, og det blev derfor foreslået at den blev indført som et supplement til de eksisterende muligheder for at tilrettelægge erhvervsuddannelser. Ny mesterlære går ud på at erstatte erhvervsuddannelsens grundforløb med mål-

\footnotetext{
${ }^{42}$ Man kan læse om projektet på http://www.uddannelse-sosu.socialfonden.net/.
} 
rettet oplæring på en virksomhed (Juul 2008) og herigennem mindske den boglige del af erhvervsuddannelsen.

Samlet set er der på de 109 uddannelser relativt færre elever af udenlandsk herkomst der er i ny mesterlære, end der er elever i ordinær praktik. I den forstand har ny mesterlære ikke levet op til de oprindelige intentioner om at bidrage til at bl.a. flere unge med udenlandsk baggrund gennemfører en ungdomsuddannelse (Juul 2008).

\section{Ord- og regnevcerksteder i forbindelse med AMU, GVU og VEUD}

I 2005 etablerede Undervisningsministeriet et forsøg med ord- og regneværksteder, rettet mod voksne på en arbejdsmarkedsuddannelse eller en erhvervsrettet uddannelse (AMU, GVU, VEUD eller voksenlærlingeforløb), med henblik på „at forbedre mulighederne for at kortuddannede deltagere i voksen- og efteruddannelse udbudt af og på erhvervsrettede uddannelsesinstitutioner kan nå målene for deres erhvervsrettede efteruddannelse“ (Møller 2009). Forsøget skulle løbe til 2008, men blev udvidet til 2009; ni skoler har deltaget $\mathrm{i}$ hele perioden. Alle ni skoler udtrykker ønske om at forsøget bliver gjort permanent, men der er ikke aftalt finansiering efter 31. december 2009 (Ramsøe 2009). EVA har evalueret forsøget og konkluderer at indsatsen imødekommer et stort behov blandt kortuddannede voksne med svage færdigheder i læsning, skrivning og regning (EVA 2009). Det særlige ved ordog regneværkstederne er at de på forskellig vis kan knyttes til og kombineres med den faglige undervisning. Forsøgsskolerne er enige om at det fungerer bedst når man benytter muligheden for at knytte værkstederne til den faglige undervisning - det gør hjælpen mere håndgribelig og meningsfuld (EVA 2009, p. 47). Det er primært ordblinde og tosprogede der har benyttet værkstederne $^{43}$. Ifølge Møller kan det skyldes at de to grupper allerede inden de kommer ind på uddannelsen, er bevidste om at de har sprogvanskeligheder som kan være en barriere for gennemførelse af uddannelsen (Møller 2009). Skolerne vurderer at kursisterne får stort udbytte af værkstederne, og at de bidrager til at flere gennemfører de faglige kurser (EVA 2009). Erfaringerne med at etablere værkstederne på skolerne er således positive, men lærerne kan mangle kompetencer i forhold til at undervise den relativt store andel tosprogede (EVA 2009, p. 54).

\footnotetext{
${ }^{43}$ Der er dog betydelige variationer med hensyn til andelen af tosprogede. På VIA på Syddansk Erhvervsskole er flertallet af brugere således tosprogede, mens andelen på EUC Sjælland er en tredjedel, og på AMU-Nordjylland og EUC Nordvestsjælland er andelen på 12-19 pct. (EVA 2009).
} 
Realkompetencevurdering inden for det formelle voksenuddannelsessystem Uddannelsesinstitutioner som udbyder almene voksenuddannelser, har pligt til at tilbyde individuel kompetencevurdering (IKV). Det er således muligt at bede om at få foretaget en IKV i forbindelse med AVU-kurser, AMU-kurser, GVU og VVU. Vurderingen kan udmønte sig i et uddannelsesbevis, kompetencebevis eller adgangsbevis og i en individuel kursusplan således at kursusforløbet er tilrettet efter de realkompetencer den enkelte kursist har fået anerkendt. I forbindelse med erhvervsuddannelser indgår IKV som en del af udarbejdelsen af en uddannelsesaftale, mens den på GVU altid skal foretages forud for start på uddannelsen, hvor den giver mulighed for at følge uddannelsen uden en uddannelsesaftale i et tempo der er tilrettelagt således at det er muligt f.eks. at passe et arbejde sideløbende (www.ug.dk).

Professionsbacheloruddannelserne til blandt andet lærer, pædagog og sygeplejerske er mellemlange videregående uddannelser af tre til fire års varighed. I 1985 blev der oprettet Forberedelseskursus for indvandrere og flygtninge (FIF) i forbindelse med pædagoguddannelserne på baggrund af stigende efterspørgsel efter tokulturelle pædagoger. Professionshøjskoler og seminarier tilbyder fortsat FIF, der varer et år, og som kræver at man har bestået en danskprøve svarende til Prøve i Dansk 3 på Danskuddannelsen. Kurserne indeholder praktikforløb; de enkelte uddannelsesinstitutioner fastlægger selv indholdet i kurset, som afsluttes med prøver i dansk sprog og dansk kultur.

FIF er flere steder etableret på baggrund af en efterspørgsel efter pædagoger, lærere, m.v. med tokulturelle kompetencer. På landsplan er det dog kun 1,2 pct. af de lærere der er uddannet siden 1991, der er tosprogede ${ }^{44}$ (Aisinger 2008).

Blandt andre Professionshøjskolen UCC har oplevet en stigning i efterspørgslen efter forberedelseskurset, og kurset har en meget høj gennemførselsrate. I 2008 søgte samtlige de kursister der bestod kurset (det gjorde 19 af et hold på 20), ind på pædagoguddannelsen.

På UCC har man endvidere fået støtte fra Integrationsministeriet til at etablere studiestøtte til tosprogede på læreruddannelsen. Erfaringerne herfra viser at, mens „,isoleret sproglig vejledning giver lavt udbytte, bliver udbyttet højere, når der etableres god sammenhæng mellem sproglig og faglig udvikling“(Integrationsministeriet 2009e).

\footnotetext{
${ }^{44}$ Tallet dækker over store regionale forskelle. Således var omkring hver tredje lærerstuderende på Københavns Dag- og Aftenseminarium (i dag en del af Professionshøjskolen UCC) tosproget i 2008 (Aisinger 2008).
} 



\section{Særlige voksen- og efteruddannelsestilbud til styrkelse af integrationen}

Der anvendes hvert år mange millioner på særlige initiativer med henblik på at styrke integrationen. Initiativerne finansieres i vidt omfang gennem Satspulje-midler, der forvaltes af ministerierne, og gennem EU's socialfond. Derudover findes andre offentlige puljer, ligesom også kommuner og virksomheder finansierer og medfinansierer en række initiativer.

Følgende kategorier vil blive anvendt i gennemgangen af særlige tiltag:

- Beskæftigelsesrettede initiativer

- Initiativer med særligt fokus på guide-/mentorordninger

- Initiativer med særligt fokus på kvinder

- Initiativer med særligt fokus på medborgerskab

Udgangspunktet for opdelingen af de gennemgåede initiativtyper har været Integrationsministeriets opdeling af de puljer de administrerer. En række af de kategorier Integrationsministeriet anvender, er ikke relevante for denne undersøgelse og er derfor ikke medtaget. Puljer som administreres af andre end Integrationsministeriet, er placeret under den betegnelse der er mest dækkende. For en lang række af puljerne, og særligt de konkrete projekter, gælder at de kan placeres under flere kategorier. Det gør sig særligt gældende for mentorordninger og initiativer rettet mod kvinder, som ofte har et beskæftigelsesrettet fokus. Kun i de tilfælde hvor mentordelen er det helt centrale i puljens formål, er de placeret i den kategori. Det tilsvarende gælder for initiativer med fokus på kvinder.

Frivillighed vil ikke blive dækket som en selvstændig kategori i denne gennemgang. Frivillighed er en selvstændig kategori i Integrationsministeri- 
ets opdeling, og det er et område der afsættes mange midler til. Således er der afsat 15 mio. om året i årene 2005-2009 af Satspuljemidlerne til Dansk Flygtningehjælps frivillige integrationsarbejde og 2,4 mio. til Dansk Røde Kors’ flygtninge- og integrationsaktiviteter i 2006-2008 og 3 mio. om året i 2009-2012. Der er yderligere puljer som kan søges til det frivillige integrationsarbejde, og såvel Dansk Røde Kors og Dansk Flygtningehjælp som andre frivillige organisationer får midler gennem de øvrige puljer til konkrete projekter. De frivillige organisationer - der udover de nævnte blandt andet omfatter Kvinfo og Foreningen Nydansker - står for og indgår som samarbejdspartnere i en række projekter inden for de fire ovenstående kategorier. Hvor det er tilfældet, vil det blive beskrevet som en del af projekterne.

\subsection{Beskæftigelsesrettede initiativer}

Der en lang række puljer under både Integrations- og Beskæftigelsesministeriet som retter sig mod at få indvandrere i beskæftigelse. Puljerne under Beskæftigelsesministeriet er generelt rettet mod „svage grupper“ på eller i kanten af arbejdsmarkedet, hvilket blandt andet omfatter forskellige grupper af indvandrere. Også EUs Socialfond støtter en række projekter der er rettet mod at få indvandrere i beskæftigelse. Projekterne under denne kategori omfatter

- Sprogpraktik

- Kombinerede forløb med vejledning/mentor, undervisning, praktik, kompetenceafklaring

- Fokus på samarbejde mellem relevante aktører

Generelt gælder det for projekterne at de foregår i samarbejde med virksomheder. Der har været en udvikling i retning af at fokusere på beskæftigelse som den primære vej til integration ${ }^{45}$, og der er afsat store midler til blandt andet at kombinere sprogundervisning og beskæftigelse/praktik. De primære puljer under Integrationsministeriet er „Virksomhedsrettet integration af nydanskere“, som omfatter støtte til erfaringsudveksling, informations- og udviklingsaktiviteter, og uddannelsesforløb, „Virksomhedsnetværk“, som støtter mentorordninger, samarbejde med virksomheder og undervisning i

\footnotetext{
${ }^{45}$ Se i øvrigt kapitel 2 vedrørende de politiske prioriteringer
} 
fagsprog. Derudover er der i 2007-2009 afsat en pulje på i alt 26 mio. til „Grundkursus i arbejdsmarkedsdansk“; puljen er blevet forlænget således at der i 2010-2012 er afsat yderligere 27 mio. Puljen er rettet mod udbydere af Danskuddannelsen, men relativt få sprogcentre har benyttet den.

De beskæftigelsesrettede initiativer er generelt kendetegnet ved et stort omfang af samarbejde mellem offentlige myndigheder, ofte kommunale jobcentre, virksomheder, sprogudbydere og frivillige organisationer. Samarbejdet mellem de relevante aktører er da også i fokus inden for denne gruppe af initiativer. En gennemgående erfaring og anbefaling fra projekterne er at samarbejdet er afgørende, ligesom kombinationer af sprogundervisning, vejledning, mentorordninger, praktik og faglig kompetenceudvikling bliver betragtet som essentielt for projekternes ret høje succesrate.

I forbindelse med sprogpraktik er fokus på den aktive brug af sproget $\mathrm{i}$ arbejde. Det bidrager ifølge Rasmussen (2008a) til øget selvtillid, øgede kommunikative kompetencer og større fokus på værdien af at beherske sproget: „langt den største del af kursisterne har brug for at blive rustet til at udnytte mulighederne for uformel læring. Den sproglige bevidsthed og forståelsen for egen læringsproces må styrkes, og kursisterne skal have mulighed for at gøre sig deres egne sproglige erfaringer i autentiske kommunikationssituationer. En systematisk kobling mellem indøvning af sproget i undervisningen og afprøvning af sproget uden for undervisningen giver kursisterne en sikker fornemmelse af sammenhængen mellem den formelle og den uformelle læring“ (Rasmussen 2008a, p. 7).

De fleste af projekterne kombinerer sprogpraktik med danskundervisning og fagundervisning. En række af projekterne samarbejder med frivillige organisationer, der typisk står for eller understøtter sprogundervisningen i form af lektiehjælp.

Et projekt der har været banebrydende i forhold til etablering af samarbejde, og som har dannet baggrund for flere nye projekter, er den såkaldte Gribskov-model, eller 44 point = arbejde. Modellen er et selvstændigt indsatsområde i initiativet „Nydanske kvinders ressourcer i fokus“. Selve modellen bygger på et pointsystem baseret på faglige standarder. Ved opnåelse af 44 point i projektets test og gennemførelse af fire ugers praktik, er man garanteret ordinær beskæftigelse på virksomheden. Modellen er udviklet i tæt samarbejde mellem virksomhed, kommune, sprogcenter, ministerium og 
et konsulentbureau ${ }^{46}$. Modellen bygger således på et intensivt vejledningsog træningsforløb kombineret med et test- og scoresystem, og omfatter derudover $2 \frac{1}{2}$ times fagrettet danskundervisning om dagen. Projektet var rettet mod kvinder på kontakthjælp med „væsentlige begrænsninger i sproglige, faglige, sociale og helbredsmæssige forudsætninger for at indgå i arbejdsstyrken“ (Integrationsministeriet 2008a). Et år henholdsvis tre måneder efter afslutningen af første og andet gennemløb er alle deltagere i ordinær beskæftigelse (Integrationsministeriet 2008a).

\subsection{Initiativer med særligt fokus på guide-/mentorordninger}

Mentorordninger er et andet højt prioriteret område; der er relativt mange puljemidler til mentorordninger - både gennem Satspuljemidlerne og gennem EU’s Socialfond. Desuden er der et mere generelt politisk fokus på området. Muligheden for mentorordninger er således indskrevet i Lov om en aktiv beskæftigelsesindsats fra 2003 (Beskæftigelsesministeriet 2003) og i Integrationsloven fra 2003 (Integrationsministeriet 2003b), med angivelse af mulighederne for at kommuner og virksomheder kan få støtte på op til 50 pct. af udgifterne i forbindelse med mentorordninger. Både Integrations-, Undervisningsog Beskæftigelsesministeriet forvalter puljer til mentorordninger. Puljerne under Undervisningsministeriet er dog primært rettet mod ungdomsuddannelser, hvilket også gælder for „pulje for uddannelsesguides“ under Integrationsministeriet, og puljerne under Beskæftigelsesministeriet er først og fremmest møntet på projekter med vejledere og konsulenter og hverken på voksen- eller efteruddannelse. I denne sammenhæng er der udelukkende fokus på de projekter der vedrører voksen- eller efteruddannelse. Det er projekter der er støttet af Integrationsministeriet og EU's Socialfond. Det drejer sig især om jobguides i forbindelse med sprogcentre og brobyggerordning.

En af erfaringerne fra de virksomhedsrettede initiativer er at matchet mellem indvandrere og virksomheder er afgørende. Det er vigtigt at fokusere på forventningsafstemning mellem virksomhed og indvandrer. Afklaringen og afdækningen af kompetencer har været centralt for jobguidefunktionerne på sprogcentre, og betydningen af tæt samarbejde mellem indvandrere un-

\footnotetext{
${ }^{46}$ Initiativtager til projektet var Gribskov kommune, der udviklede modellen sammen Københavns Hotel- og Restaurationsservice, Sprogcenter Nordsjælland, konsulentbureauet Servisio og Integrationsservice.
} 
dervisere, vejleder, jobkonsulenter og virksomheder fremhæves. Tove Rasmussen (2008c) identificerer praktik, jobformidling og samarbejde med det lokale arbejdsmarked som de væsentligste opgaver for jobguides på sprogcentre.

Det fremhæves i flere af evalueringerne af guide- og mentorprojekter at de har bidraget til at indvandrerne ,sætter mere realistiske mål i relation til erhvervsvalg senere“. I forhold til at komme i arbejde anses det altså for afgørende at indvandrerne accepterer at de starter i beskæftigelse som de rent fagligt må betragtes som overkvalificerede til. Således konkluderer Integrationsministeriet i evalueringen af projektet „Klar Parat Job“, at det ... har motiveret borgere til at indstille sig på at arbejdspladslæring af dansk nogle gange godt kan få forrang for hvor mange af sine faglige kvalifikationer man anvender. Derfor er en del kursister startet på en niveau under det, deres faglighed måske berettigede til - til gengæld har de fået arbejde, og giver nu udtryk for et langsigtet mål om at kvalificere sig til højere stillinger når det sproglige niveau er tilsvarende højnet“ (Integrationsministeriet 2009b).

Mentorordninger er ifølge Nørregård (2007) med til at give tryghed og støtte til udfordringer i hverdagen og til at fastholde indvandrerne på arbejdsmarkedet. Et meget vellykket mentorprojekt var Brobyggerordningen som fungerede fra 2001-2003, og som var med til at inspirere til at mentorordninger blev integreret i beskæftigelseslovgivningen. 84 pct. af deltagerne i projektet kom i beskæftigelse eller uddannelse, primært ordinær beskæftigelse i ufaglærte jobs i den private sektor. En af de ting der blev peget på, var at mentorerne var oplagte til at give input til danskundervisningen og til at hjælpe med at identificere områder hvor der var behov for sproglig opkvalificering. Erfaringen var derudover at ordningen havde fungeret positivt både i forhold til at fastholde indvandrerne i arbejde, til at aflive myter og til at påvirke holdninger i virksomhederne, hvorved disse blev mere tilbøjelige til at rekruttere indvandrere.

\subsection{Initiativer med særlig fokus på kvinder}

Ifølge Integrationsministeriet er „køn stadig (...) en barriere for en vellykket integration for en del kvinder med etnisk minoritetsbaggrund“ (Integrationsministeriet 2009f). 
Der er i de seneste år afsat omfattende midler til initiativer med særligt fokus på kvinder med indvandrerbaggrund. I årene 2007-2011 er der således afsat i alt 55,6 mio. af Satspuljemidlerne til „Kvindeprogrammet“, som dækker områderne „kvinders betydning for familiens og børns integration“, „kvinders netværk“ og „kvinders beskæftigelse og iværksætteri“. Ud over denne indsats har en lang række kommuner selv iværksat initiativer med fokus på uddannelse af kvinder med indvandrerbaggrund.

De projekter der er rettet specifikt mod kvinder, er da også stort set alle rettet mod marginaliserede kvinder der umiddelbart har ringe forudsætninger for at komme i beskæftigelse. Derfor bliver effekter der umiddelbart virker lave, betegnet som tilfredsstillende. Det gælder blandt andet LG Insights samlede evaluering af projekterne under puljen „den beskæftigelsesfremmende indsats for flygtninge- og indvandrerkvinder samt familiesammenførte“, hvor man konkluderer som positivt at 28 pct. af deltagerne var blevet selvforsørgende efter projekternes ophør (LG Insight 2006a, p. 4). Projekterne har blandt andet omfattet coachforløb, metoder til kompetenceafklaring, sprogundervisning, udvikling af nye vejledningsmetoder, motivationsopbyggende forløb og fokus på hele familien. Derudover har disse projekter også fokuseret på brede samarbejdskonstellationer mellem kommuner, sprogskoler, uddannelsesinstitutioner, virksomheder, boligforeninger, frivillige organisationer, faglige organisationer, m.m. Nogle af anbefalingerne fra projekterne lyder på at fokusere på indsatser med et meget klart jobmæssigt perspektiv - også i forhold til kvinder der har en meget lav arbejdsmarkedsparathed - og at prioritere et tæt samarbejde med virksomheder (LG Insight 2006a, p. 7).

\subsection{Initiativer med særligt fokus på medborgerskab}

Den sidste kategori der berøres her, er initiativer med fokus på medborgerskab. Medborgerskab og målet om at kunne „fungere som aktiv medborger i samfundet“ er - udover målsætningen om beskæftigelse og selvforsørgelse en central del af integrationsmålet i Integrationsloven. Men medborgerskab, etableringen af netværk og deltagelse i foreningsliv betragtes også som en vigtig faktor til at øge mulighederne for at komme i uddannelse eller arbejde. Der er relativt store puljer under Satspuljen til „øget dialog og forståelse på tværs af etniske og religiøse grupper“, ,fremme af ligebehandling og mang- 
foldighed“ og til „fremme af det frivillige integrationsarbejde og deltagelse i idræts- og foreningslivet“. Projekterne under puljerne er især bygget op omkring netværksdannelse, dialog og sociale aktiviteter. En del af dem har undervisning, foredrag og lektiehjælp som nogle af de faste aktiviteter man mødes om.

Projekter der retter sig mod medborgerskab, er først og fremmest bygget op om etablering af netværk, typisk på baggrund af sociale arrangementer (fællesspisning, bowling, m.m.), foredrag eller lektiehjælp. Der er meget ofte frivillige organisationer med i projekterne, typisk i forbindelse med lektiehjælp eller med henblik på at træne hverdagssproget i mere uformelle samtaler. De to ting kombineres dog tit, således at samtalerne tager udgangspunkt i sprogundervisningen. Det er blandt andet tilfældet i projektet „Bedre dansk“ på Sprogcentret Haderslev, som på den baggrund har observeret en sproglig og samfundsfaglig styrkelse og derudover mener at kunne se at flere af indvandrerne begynder at etablere et reelt netværk med de frivillige.

\section{References}

Aisinger (2008).

„Hver tredje lærerstuderende på KDAS er tosproget“, http://www.folkeskolen.dk/ ObjectShow.aspx?ObjectId=51697

Besøgt 17.09.2009.

Ballerup Sprogcenter (2009). Årsberetning 2008 Ballerup Sprogcenter: Ballerup.

Bertelsen, Ellen, Susanne Lodberg, Gert Palle Andersen, Michael Tødten, Caspar Christensen og Karen Lund (red.) (2006).

Dansk som andetsprog anvendt fleksibelt $i$ $A M U$. Holbæk: EUC Nordvestsjælland Beskæftigelsesministeriet (2003).

Lov om en aktiv beskceftigelsesindsats, lov nr. 419 af 10. juni 2003, Beskæftigelsesministeriet

Bie, Charlotte og Lene Timm (2005).

Evaluering af „Dansk på vej til arbejde“ - et projekt gennemført af Sprogcenter Nordsjcelland i samarbejde med Rørmosegård I/S, VUC Nordsjæelland og FVU-konsulenten i Frederiksborg Amt med støtte fra EU's Socialfond, mål 3, København: UC2.

Birk Nielsen, Hanne (2006).

„FVU som sprogcentertilbud“, pp. 10-12 i Sprog og Integration, nr. 3, oktober 2006. København: UC2.

Borberg, Hjarn Zernichow (2000).

„Den forberedende voksenundervisning i støbeskeen“, Undervisningsministeriet, http://udd.uvm.dk/200005/udd051.htm?menuid $=4515$

Bruun, Inger (2006).

Danskuddannelse til voksne udlcendinge m.fl. - information til vejledere og integrationsmedarbejdere: Rådet for Uddannelses- og Erhvervsvejledning.

BT (2000).

S-borgmestre: hjcelp os, Thorkild, B.T. 5. januar 2000.

Carter, Jessica, Kjeld Kjertmann, Lars Klewe og Inge B. Larsen (2004).

Forberedende Voksenundervisning (FVU) - en undersøgelse af erfaringerne med 
FVU. København: Danmarks Pædagogiske Universitet.

Cubion (2008).

Evaluering af Projekt want2work; Asylafdelingen, Dansk Røde Kors.

Danmarks Statistik (2008).

Indvandrere i Danmark 2008, København: ParitasDigitalPrint.

Deloitte (2007).

Undersøgelse af danskuddannelsens modultakstsystem; Integrationsministeriet.

Den Store Danske, Gyldendals åbne encyklopædi; www.denstoredanske.dk, besøgt sidste gang 24. oktober 2009.

DMA Research (2005).

Evaluering af VUC - VUC-kursister; København: DMA/Research.

Due, Helen (2006).

„Pædagogisk udvikling kan kun lære lærerne at trylle, ikke at udrette mirakler...“, p. 13, i Sprog og Integration, nr. 3, oktober 2006. København: UC2.

Elsborg, Steen (2009).

Styrket motivation for deltagelse i AMUaktiviteter - hvad skal der til? Sammenfatning af erfaringer fra udviklingsprojekter gennemført med TUP-midler 2007-2008. København: Nationalt Center for Kompetenceudvikling.

EMPH (2008).

„Man oplever ligesom Danmark på en helt ny måde" - en evaluering af højskolernes kommunepuljeprojekt, København: EMPH.

Erhvervs- og selskabsstyrelsen (2006).

Lovforslag nr. L95, Folketingsåret 2006/2007. Styrket lcese-, skrive- og regneindsats, http://eogs-lw.lovportaler. $\mathrm{dk} /$ showdoc.aspx?hashparam= v\&schultzlink=lfo20067095

Eriksen, Morten, Niels Aagaard og Marit Schiødt (2004).

Evaluering af brobyggerordningen; CABI.

EVA (2005a).

VUC - AVU og enkeltfags-hf. København: Vester Kopi.

EVA (2005b).
Forberedende voksenundervisning. Kvantitativ undersøgelse blandt deltagerne. København: Vester Kopi.

EVA (2007).

Grunduddannelse for voksne (GVU), København: Vester Kopi.

EVA (2008).

Videregående Voksenundervisning, http://www.eva.dk/projekter/2009/vvu.

EVA (2009).

Forsøg med ord- og regnevcrksteder, Danmarks Evalueringsinstitut, www.eva.dk.

Finansministeriet, Arbejdsministeriet og Undervisningsministeriet (1999).

Mål og midler i offentligt finansieret voksen- og efteruddannelse, København: Schultz Grafisk.

Finansministeriet (2006a).

Livslang opkvalificering og uddannelse for alle på arbejdsmarkedet - rapport fra Trepartsudvalget. Bind 1: Den fremtidige voksen- og efteruddannelsesindsats, Albertslund: Schultz Grafisk.

Finansministeriet (2006b).

Livslang opkvalificering og uddannelse for alle på arbejdsmarkedet - rapport fra Trepartsudvalget. Bind 2: Kortlcegning og analyser, Albertslund: Schultz Grafisk.

Finkelstein, Jens og Anders K. Kristensen (2004).

Mentor i beskceftigelsesindsatsen; FOKUS

Frimodt, Rasmus og Jørgen Ole Larsen (2009).

EUD og integration af flygtninge og indvandrere - i et europceisk perspektiv; Nationalt Center for Erhvervspædagogik, Professionshøjskolen Metropol. Gotenborg, Birgit, Susanne Bomholt Andersen, Elsebeth Pedersen og Werner Hedegaard (2008).

Realkompetence - parat til GVU-start på SOSU; Undervisningsministeriets håndbogsserie nr. 6, 2008. København: Undervisningsministeriet.

Hamburger, Charlotte (1997): 
„Etniske minoriteter og den sociale integration“, i Zeuner, Lilli (red.): Social integration, Socialforskningsinstituttet, København.

Hjermov, Birgit, Anne Mette Rasmussen og Sofie Saxtoft (2007).

Rengøringsbranchens mangfoldighed en udfordring for AMU?. København: Kubix.

Husted, Leif (2008).

Danskuddannelse for voksne udlcendinge 2004-2006 - progression og benchmarking: Anvendt KommunalForskning (AKF).

IA Sprog (2008).

Årsberetning 2008: IA Sprog.

Integrationsministeriet (2002).

Lov om æendring af integrationsloven, lov nr. 364 af 6. juni 2002; Ministeriet for flygtninge, indvandrere og integration.

Integrationsministeriet (2003a).

Lov om danskuddannelse til voksne udlandinge m.fl., lov nr. 375 af 28. maj 2003; Ministeriet for flygtninge, indvandrere og integration.

Integrationsministeriet (2003b).

Lov om æendring af integrationsloven og udlcendingeloven, lov nr. 425 af 10 . juni 2003; Ministeriet for flygtninge, indvandrere og integration.

Integrationsministeriet (2005).

„Højskole hjælper integrationen på vej“, p. 6 i I job nu, Integrationsministeriets nyhedsbrev, nr. 2, 3. årg.

Integrationsministeriet (2006a).

Bekendtgørelse af lov om danskuddannelse til voksne udlcendinge m.fl., lbk nr. 259 af 18. marts 2006; Ministeriet for flygtninge, indvandrere og integration. Integrationsministeriet (2006b).

Bekendtgørelse af lov om integration udlændinge i Danmark, lbk nr. 902 af 3. juli 2006; Ministeriet for flygtninge, indvandrere og integration.

Integrationsministeriet (2008a).

Gribskovmodellen. www.nyidanmark.dk/ da-dk/integration/erfaringsbasen/ 2008/04/1158434.htm
Integrationsministeriet (2008b).

Nydanske medarbejdere i små og mellemstore virksomheder: Ministeriet for flygtninge, indvandrere og integration. Integrationsministeriet (2008c).

Faktaark om Danskuddannelse: Ministeriet for flygtninge, indvandrere og integration.

Integrationsministeriet (2009a).

Jobguide på AOFSYD Sprogcenter. www.nyidanmark.dk/da-dk/integration/ erfaringsbasen/2009/02/1518693.htm

Integrationsministeriet (2009b).

Klar Parat Job - Et uddannelses- og arbejdsmarkedsforberedende forløb for selvforsørgende integrationslovsborgere. www.nyidanmark.dk/da-dk/ integration/erfaringsbasen/2009/ 04/1512815.htm

Integrationsministeriet (2009c).

Projekt Sprogbad. www.nyidanmark.dk/ da-dk/integration/erfaringsbasen/ 2009/04/1623651.htm

Integrationsministeriet (2009d).

Jobguide på Sprogcentret VejleFredericia. www.nyidanmark.dk/da-dk/ integration/erfaringsbasen/2009/07/ 1692695.htm

Integrationsministeriet (2009e).

Model til studiestøtte for tosprogede (leereruddannelse), http://www. nyidanmark.dk/da-dk/integration/ erfaringsbasen/2009/07/1776429.htm Besøgt 07.08.2009.

Integrationsministeriet (2009f).

Integrationsindsats for kvinder og familier. http://www.nyidanmark.dk/da-dk/ Integration/fokuspaakvinder/ Integrationsindsats_for_kvinder_og familier/beskaeftigelse_og uddannelse.htm. Besøgt 09.10.2009.

Integrationsministeriet (2009g).

Vejledning om introduktionsprogrammet m.v. efter integrationsloven, juni 2009. Integrationsministeriet (2009h). Hava Familie og integration, http:// www.nyidanmark.dk/da-dk/integration 
/erfaringsbasen/2009/08/1664699.htm

Besøgt 11.11.2009.

Juul, Ida (2008).

Fastholdelse og lcering i ny mesterlcere og i skoleadgangsvejen, København: Undervisningsministeriets centrale analyse- og prognosevirksomhed til erhvervsuddannelserne 2008.

Jørgensen, Jan Reitz (2007).

Danmarks strategi for livslang leering Uddannelse og livslang opkvalificering for alle, redegørelse til EU-kommissionen april 2007; Werner Hedegaard, Undervisningsministeriet.

Klewe, Lars (2008).

AVU, Almen voksenuddannelse - kursisternes baggrund og valg af uddannelse og erhverv efter AVU, årgang 1995 og 2002, København: Danmarks Pædagogiske Universitetsskole ved Århus Universitet og Københavns VUC.

Landsorganisationen i Danmark, Dansk Arbejdsgiverforening, KL, Ministeriet for flygtninge, indvandrere og integration og Arbejdsmarkedsstyrelsen (2006).

Få tilskud til en mentor - det ender med at blive en god investering; Integrationsministeriet.

LG Insight (2006a).

Evalueringsrapport „Den beskæftigelsesfremmende indsats for flygtninge- og indvandrerkvinder samt familiesammenførte“, Pulje under Ministeriet for flygtninge, indvandrere og integration, august 2006, LG Insight.

LG Insight (2006b).

„44 POINT=ARBEJDE“, evaluering af et beskæftigelsesinitiativ for kvinder med anden etnisk baggrund end dansk; Gribskov Kommune, Integrationsministeriet. Lindberg, Else (2000).

„Prøver i dansk som andetsprog for voksne udlændinge - udvikling af et nyt prøvesystem“, Uddannelse 4/2000, Undervisningsministeriet

Lou, Jette (2009).
„Mere fleksibelt danskundervisningstilbud til udenlandske arbejdstagere“; pp. 1-7 i Det Flyvende Tappe, vol. 12. Lund, Karen og Ellen Bertelsen (2008).

Fra Studieprøven til de videregående uddannelser. En undersøgelse af de nødvendige og tilstrækkelige kompetencer, København: Ministeriet for flygtninge, indvandrere og integration.

Lysholm, Inger, Åse Iversen og Henning Kalsgaard Poulsen (2004).

To-sprogedes udbytte af FVUundervisning, http://www.kompetenceafklaringstilbud.dk/upload\%5Cffa63db 806404d21add7c77703d87706/FVU\%2 0dansk\%20for\%20tosprogede.doc

LXP Consulting (2007).

Evaluering af Integrationsministeriets pulje for uddannelsesguides; Ministeriet for flygtninge, indvandrere og integration.

MHTConsult (2008).

SOSU som sluse til job og uddannelse. Slutevaluering af Equalprojektet „Fremme af uddannelse og beskæftigelse inden for social- og sundhedsområderne for kvinder med anden etnisk baggrund end dansk“. Sammenfatning af konklusioner, MHTConsult.

MHTConsult (2009).

„VIP2“. Procesevaluering af Virksomhedsrettet Integration Projekt 2 - Sammenfatning af konklusioner og anbefalinger, MHTConsult.

Morel, Jean-Pierre (2004).

„Evalueringen af projekt Virksomhedsbaseret integration"; CABI

Morell, Peter, Irene Mortensen og Anne Mølgaard (2004).

Aspekter af mentorskab. Potentialer ved mentorordninger i den virksomhedsrettede integration af flygtning og indvandrere; CABI

Møller, Susanne (2009).

Ord- og regneværksteder - Erfaringer og ideer fra erhvervsrettet voksen- og efteruddannelse; Undervisningsministeriets temahæfteserie nr. 6 - 2009; København: Afdelingen for erhvervsrettet 
voksenuddannelse, Kontor for livslang læring, Undervisningsministeriet

Netværkslokomotivet (2009).

Evaluering af Netværkslokomotivets aktiviteter 2008, marts 2009.

Norlyk Jens (2009).

Erhvervsrettet andetsprogsdansk i erhvervsuddannelserne - råd og vink, Undervisningsministeriet, juni 2009.

Nørregård, Susie Skov (2007).

Mentorordningen i beskæftigelsesindsatsen - en undersøgelse af brugen af mentorordninger i arbejdet med beskæftigelse af nydanskere; Mentorkompagniet; Ministeriet for flygtninge, indvandrere og integration.

Pedersen, Michael Svendsen (2006a). når man ikke kender historien. Rapport over erfaringer med „Initiativer med særligt fokus på integration af flygtninge og indvandrere m.fl. i EUD og AMU“, Institut for Uddannelsesforskning, Roskilde Universitetscenter.

Pedersen, Michael Svendsen (2006b). At gøre en forskel. Rapport nr. 2 over erfaringer med ,Initiativer med særligt fokus på integration af flygtninge og indvandrere m.fl. i EUD og AMU“, Institut for Uddannelsesforskning, Roskilde Universitetscenter.

Rambøll Management (2007).

Med moduler som motor. Evaluering af danskuddannelsesloven; Aarhus: Ministeriet for flygtninge, indvandrere og integration.

Rambøll (2008a).

Evaluering af jobpakker; Arbejdsmarkedsstyrelsen, København: Rambøll Management.

Rambøll (2008b).

Evaluering af projekter for personer på kanten af arbejdsmarkedet; Arbejdsmarkedsstyrelsen.

Ramsøe, Annette (2007a).

Infobrev om Handlingsplan for kvalificering af flygtninge og indvandrere via AMU-programmet m.v., sagsnr. 146.964.021, 18. juni 2007, Køben- havn: Undervisningsministeriet, Afdelingen for Erhvervsrettet voksenuddannelse.

Ramsøe, Annette (2007b).

„Ny kort og fleksibel arbejdsmarkedsuddannelse i dansk som andetsprog“, p. 4 i Det Flyvende Tæeppe, nr. 5, 2007.

Ramsøe, Annette (2009).

„Evaluering viser, at mange tosprogede benytter ord- og regneværksteder“, p. 3-4 i Det Flyvende Tceppe, nr. 13, 2009.

Rasmussen, Tove (2008a).

Den gode praktik - idéer til forberedelse, gennemførelse og efterbehandling af sprogpraktik; UC2, Professionshøjskolen UCC, København N.

Rasmussen, Tove (2008b).

Dansk Nok! Evaluering af et udviklingsprojekt på Sprogcenter Nordsjælland støttet af Den europæiske Socialfond; UC2, Professionshøjskolen København.

Rasmussen, Tove (2008c).

At kunne give nogen en chance; UC2, Professionshøjskolen UCC, København.

Regeringen (2002a).

En ny udlcendingepolitik, 17. januar 2002.

Regeringen (2002b).

På vej mod en ny integrationspolitik, 5 . marts 2002.

Regeringen (2002c)

Aftale om „Flere i arbejde“, 7. oktober 2002.

Regeringen (2003).

Regeringens vision og strategier for en bedre integration, 16. juni 2003.

Regeringen (2005a).

Nye mål, regeringsgrundlag, februar 2005. Regeringen (2005b).

En ny chance til alle - regeringens integrationsplan, maj 2005; Ministeriet for flygtninge, indvandrere og integration.

Regeringen (2005c).

Beskcftigelse, deltagelse og lige muligheder til alle - regeringens handlingsplan for at nedbryde kønsbestemte barrierer til uddannelse, arbejde og foreningslivet blandt kvinder og mand med anden 
etnisk baggrund end dansk, Minister for ligestilling.

Regeringen (2006a).

Fremgang, fornyelse og tryghed - strategi for Danmark i den globale økonomi, april 2006.

Regeringen (2006b).

Aftale om fremtidens velstand og velfcerd og investeringer i fremtiden. Aftale om fremtidig indvandring, 20. juni 2006.

Rektorkollegiet (2001).

Integration af fremmedsprogede studerende på de lange videregående uddannelser, Århus: Phønix-Trykkeriet A/S.

Seeberg, Peter (2002).

Unge indvandreres integration, herunder integration gennem gymnasiet, fritidsaktiviteter, kærester mv., AMID Working Paper Series 27/2002, Aalborg: AMID, Institut for Historie, Internationale Studier og Samfundsforhold, Aalborg Universitet.

Semey, Mette og Sofie Saxtoft (2007).

Lærer med mere. Jopprofiler og efteruddannelsesbehov for AMU-lærere. København: Kubix.

Sprogcenter Nordsjælland (2008).

Arsberetning 2008.

Sprogcenter Vejle (2008).

Prcesentation SprogCenterVejle - i dialog med omverden.

Statsministeriet (2001).

Regeringsgrundlag 2001, Vækst, velfærd - fornyelse.

Svensson, Iben (2008).

VUC - et flerkulturelt uddannelsessted, pp. 24-26 i Sprog og Integration, nr. 3, oktober 2008, København: UC2.

Svensson, Iben (2009).

AVU-reform signalerer nyt syn på tosprogethed, pp. 22-24 i Sprog og Integration, nr. 1, marts 2009, København: UC2.

UCC (2009).

Flere indvandrere vil være pædagog, http://www.ucc.dk/omucc/aktuelt/nyheder/flereindvandrerevilvaerepaedagog.h tmlbesøgt 10.10.2009.
Undervisningsministeriet (1998).

Lov om undervisning i dansk som andetsprog for voksne udlcendinge m.fl. og sprogcentre, lov nr. 487 af 1. juli 1998.

Undervisningsministeriet (2000a).

Bekendtgørelse om undervisning m.v. inden for forberedende voksenundervisning (FVUbekendtgørelsen), bek 1200 af 15 . december 2000, København: Undervisningsministeriet.

Undervisningsministeriet (2000b).

Bekendtgørelse om grunduddannelse for voksne (GVU), bek nr. 1405 af 22. december 2000, København: Undervisningsministeriet.

Undervisningsministeriet (2003a).

AMU under forandring - om reformen fra 2004, København: Undervisningsministeriet.

Undervisningsministeriet (2003b).

Lov om arbejdsmarkedsuddannelser m.v., lov nr. 446 af 10. juni 2003, København: Undervisingsministeriet.

Undervisningsministeriet (2004a).

Vejledning til AMU's program for flygtninge og indvandrere, vejledning $\mathrm{nr}$. 9216 af 29. april 2004, København: Undervisningsministeriet.

Undervisningsministeriet (2004b).

Bekendtgørelse af lov om grundlæggende social- og sundhedsuddannelser, lbk. nr. 823 af 15. juli 2004, København: Undervisningsministeriet.

Undervisningsministeriet (2005).

Bekendtgørelse af lov om forberedende voksenundervisning (FVU-loven), lbk nr. 16 af 17. januar 2005, København: Undervisningsministeriet.

Undervisningsministeriet (2006a).

Håndbog i AMU's tilbud til flygtninge og indvandrere; Undervisningsministeriets håndbogsserie nr. 16 - 2006; Undervisningsministeriets håndbogsserie nr. 16, 2006. København: Undervisningsministeriet

Undervisningsministeriet (2006b). 
Bekendtgørelse af lov om almen voksenuddannelse, lbk 852, af 11 . juli 2006, København: Undervisningsministeriet. Undervisningsministeriet (2007a).

Lov om ændring af lov om forberedende voksenundervisning og ordblindeundervisning for voksne, lov nr. 557 af 6 . juni 2007, København: Undervisningsministeriet.

Undervisningsministeriet (2007b).

Bekendtgørelse af lov om uddannelsen til højere forberedelseseksamen (hf-loven), lov nr. 445 af 8. maj 2007, København: Undervisningsministeriet.

Undervisningsministeriet (2007c).

Bekendtgørelse om gymnasial supplering (GS-bekendtgørelsen), bek nr. 1493 af 12. december 2007, København: Undervisningsministeriet.

Undervisningsministeriet (2007d).

Infobrev om Handlingsplan for kvalificering af flygtninge og indvandrere via AMU-programmet m.v.; sagsnr. 146.964.021, 18. juni 2007. København: Undervisningsministeriet, Afdelingen for erhvervsrettet voksenuddannelse.

Undervisningsministeriet (2007e).

Bekendtgørelse om ændring af bekendtgørelse om grunduddannelse for voksne (GVU), bek. Nr. 325 af 30. marts 2007, København: Undervisningsministeriet. Undervisningsministeriet (2007f).

Lov om ændring af lov om erhvervsuddannelser og forskellige andre love og om ophævelse af lov om grundlæggende social- og sundhedsuddannelser og lov om landbrugsuddannelser, lov nr. 561 af 6. juni 2007, København: Undervisningsministeriet.

Undervisningsministeriet (2007g).

Lov om ændring af forskellige love på Undervisningsministeriets område, lov nr. 556 af 6. juni 2007, København: Undervisningsministeriet.

Undervisningsministeriet (2008).

Lov om almen voksenuddannelse og om anerkendelse af realkompetence i for- hold til fag i almen voksenuddannelse, i hf-uddannelsen og i uddannelsen til studentereksamen (avu-loven), lov nr. 311 af 30. april 2008, København: Undervisningsministeriet.

Undervisningsministeriet (2009a).

Bekendtgørelse om almen voksenuddannelse (avu-bekendtgørelsen), bek nr. 292 af 1. april 2009, København: Undervisningsministeriet.

Undervisningsministeriet (2009b).

Afrapportering af handlingsplan for kvalificering af flygtninge og indvandrere via AMU-programmet, 12. maj 2009, København: Undervisningsministeriet, Kontor for Livslang læring.

Undervisningsministeriet (2009c).

Oversigt over AMU-kurser for flygtninge og indvandrere og praktik, samt IKV for flygtninge og indvandrere, 9. juli 2009. http://www.uvm.dk/ /media/Files/Udd/ Voksne/PDF09/090716_Oversigt_ over_nye_og_gamle_FogI_kurser.ashx. Velfærdsministeriet (1998).

Lov om integration af udlcendinge i Danmark, lov nr. 474 af 1. juli 1998.

Werngreen, Niels Chr. Og Tony Elmstrøm (2006).

Veje til viden - erfaringer fra Family Learning og FVU i Århus og på Djursland, Silkeborg: Silkeborg Bogtryk.

Winther, Dagmar (2006).

Samarbejde med Pæd.Seminarium, pp. 13-14 i Fra Rønde Høj- og Efterskole nr. 3, oktober 2006, Rønde Høj- og Efterskoles elevforening.

Wissing, Lisbeth og Ulla Naumann (2009).

„Når dansk er fremmedsprog“ , pp. 8-9 i Gymnasieskolen, årg. 92, nr. 3.

www.dfs.dk. 84 forældre begynder sprogundervisning i Rosenhøj, Dansk Folkeoplysnings Samråd.

www.ug.dk. Uddannelsesguiden, besøgt jævnligt i perioden februar-november 2009. 